\title{
Zooplankton fluctuations in Jurumirim Reservoir (São Paulo, Brazil): a three-year study
}

\author{
Sartori, LP. ${ }^{\mathrm{a}}$, Nogueira, MG. ${ }^{\mathrm{a}}$, Henry, R. $^{\mathrm{a}}$ and Moretto, EM. ${ }^{\mathrm{b}}$ \\ ${ }^{\text {a}}$ Departamento de Zoologia, Instituto de Biociências, \\ Campus de Botucatu, Universidade Estadual Paulista - UNESP \\ Rubião Júnior, CEP 18618-000, Botucatu, SP, Brazil \\ bEscola de Artes, Ciências e Humanidades - EACH, \\ Universidade de São Paulo - USP, \\ Rua Arlindo Bettio, 1000, Ermelino Matarazzo, CEP 03828-000, São Paulo, SP, Brazil \\ *e-mail: lpsartori@yahoo.com.br
}

Received February 15, 2007 - Accepted August 20, 2007 - Distributed February 28, 2009

(With 13 figures)

\begin{abstract}
During three consecutive years, monthly samples of zooplankton were taken in the lacustrine (dam) zone of Jurumirim (São Paulo, Brazil). The seasonal effect on basic limnological features (thermal regime, oxygen distribution, phytoplankton biomass, etc.) was also examined. The influence of the seasonality on the fluctuation of the zooplankton composition and abundance was not clearly detected (low degree of recurrent patterns). Rotifers (32 taxa) were the most abundant organisms during almost the entire study period with some seasonal alternations in the maximum abundance peaks of the main taxa (Conochilus unicornis, Keratella americana, K. cochlearis and Hexarthra spp.), except for Polyarthra (mainly P. vulgaris). Only occasionally copepods were numerically dominant. Higher copepod abundance was positively associated to periods of increase in the water retention time. Among the Copepoda (10 taxa) the calanoids (mainly Notodiaptomus iheringi) were more abundant, especially in warmer periods. Conversely, cyclopoids had higher abundance in autumn and winter. The species Thermocyclops minutus and T. decipiens co-occurred, but the first attained higher abundance. Some evidence of co-existence strategies between both species are considered. Cladocera (17 taxa) was never numerically dominant and the main taxa (Bosmina spp., Ceriodaphnia spp. and Diaphanosoma spp.) occurred almost the whole study period and did not present a seasonal pattern of fluctuation. Diaphanosoma (mainly D. birgei) attained the highest abundance among cladocerans. Most organisms were always found at the surface, but they also occupy the whole water column, even in periods of stratified conditions and low oxygen concentration in the bottom layers. Among the main zooplanktonic taxa, only Hexarthra avoids deep layers. An exceptionally high concentration of Copepoda nauplii on the surface was influenced by low transparency, high concentration of phytoplankton at this layer and low oxygen concentration at the bottom. In periods of higher retention timevariability there was a more heterogeneous distribution of the zooplankton in the water column. The increase in the retention time seems also to favor the copepod development. Finally, some inter-decade changes are considered on the basis of zooplankton assemblage structure observations.
\end{abstract}

Keywords: tropical reservoir, fluctuation, Cladocera, Copepoda, Rotifera.

\section{Flutuaç̃̃es do zooplâncton na represa de Jurumirim (São Paulo, Brasil): um estudo de três anos}

\begin{abstract}
Resumo
Durante três anos consecutivos, foram feitas amostragens mensais do zooplâncton na zona lacustre (barragem) do reservatório de Jurumirim. Os efeitos da sazonalidade nas características limnológicas básicas (regime térmico, distribuição do oxigênio, biomassa fitoplanctônica, etc.) também foram examinados. Um padrão de flutuação da composição zooplanctônica e da sua abundância não foi claramente detectado (baixo grau de recorrência interanual). Os rotíferos foram os organismos mais abundantes durante a maior parte do tempo, com alterações nos picos de abundância dos principais táxons (Conochilus unicornis, Keratella americana, K. cochlearis e Hexarthra spp.), exceto para Polyarthra (principalmente P. vulgaris). Apenas ocasionalmente, os copépodes foram numericamente dominantes, estando esse fato relacionado a períodos de aumento no tempo de residência da água. Entre os Copepoda (10 táxons), os calanóides (principalmente Notodiaptomus iheringi) foram mais abundantes, especialmente em períodos mais quentes. Por outro lado, os ciclopóides foram mais abundantes no outono e no inverno. As espécies Thermocyclops
\end{abstract}


minutus e T. decipiens coocorreram, mas a primeira alcançou maior abundância. Algumas estratégias de coexistência entre ambas as espécies são consideradas. Cladocera (17 táxons) nunca foi dominante numericamente e os principais gêneros (Bosmina, Ceriodaphnia e Diaphanosoma) ocorreram durante quase todo o período de estudo e não apresentaram um padrão sazonal de flutuação. Diaphanosoma birgei foi o táxon mais abundante entre os cladóceros. Embora a maioria dos organismos ocupasse toda a coluna d'água, mesmo em períodos de estratificação térmica e baixas concentrações de oxigênio no fundo, foram sempre mais abundantes na superfície. Entre os principais táxons zooplanctônicos, apenas Hexarthra evitou camadas profundas. A alta concentração de náuplios de Copepoda na superfície foi influenciada pela baixa transparência, alta concentração do fitoplâncton nesta camada e baixa concentração de oxigênio no fundo. Nos períodos de maior variabilidade do tempo de retenção, houve uma distribuição mais heterogênea do zooplâncton na coluna d'água. O aumento de tempo de retenção também favorece o desenvolvimento dos copépodes. Finalmente, algumas considerações sobre as mudanças entre-décadas são feitas, baseadas em observações da estrutura da assembléia zooplanctônica.

Palavras-chave: reservatório tropical, flutuações, Cladocera, Copepoda, Rotifera.

\section{Introduction}

All temporal changes that occur in ecosystems are complex and may be responsible for cyclic patterns of variation. Different periods of time, such as days or years, are reflected in the organism. If the individual lifetime is short, in relation to environmental changes, oscillations or fluctuations of the population density are expected. If individual life is long, or if the considered period is too short, the environmental modifications affect only the activities, rhythms and behavior, such as in feeding and spatial distribution. This last kind of change does not influence the total number of individuals in the population (Margalef, 1974).

The continuous replacement of species is one of the most remarkable characteristics of the plankton communities, being the theme of several classical studies (Hutchinson, 1967; Edmondson and Litt, 1982). The period of time along a seasonal cycle determines conspicuous modifications in the community structure, and a real ecological succession with changes in the species composition is expected. Such modifications overlap brief fluctuations and rhythms, partly due to great alterations in the environment among the seasons, and also due to the briefness of the life of the organisms (Hutchinson, 1967; Margalef, 1974).

The search for patterns that explain plankton periodicity has been exhaustive, resulting in a huge literature and generating theoretical models especially applied to the phytoplankton dynamics in temperate regions (Reynolds, 1984). In the case of zooplankton, studies still do not have a synthesis character, and generally the factors that interfere in the temporal dynamics of the populations have been analyzed individually.

According to Talling and Lemoalle (1998), despite some comprehensive studies in individual sites, more generalized approaches focusing on time-variability in the tropics are scanty. For zooplankton, these authors pointed out that even in environments with a well-defined stratification-mixing cycle (e.g. Lake Titicaca), the changes in populations do not seem to be closely related to thermal regime, showing much irregularity in patterns.
More recently, new hypotheses have been posited to try to explain temporal variation patterns in plankton communities, such as the intermediate disturbance hypothesis (Flöder and Sommer, 2000), originally developed to explain the high diversity of coral reefs and tropical forests (Connell, 1978). Most of these studies are related to phytoplankton assemblages (Reynolds, 1993), and few are related to zooplankton. Keppeler and Hardy (2004) concluded that the structure of tropical zooplankton communities under the influence of intermediate perturbations (e.g. water level fluctuation) has a disturbed successional development, according to the level of the established diversity.

In artificial reservoirs, climatological forces (precipitation, wind, solar radiation and temperature), and other proper mechanisms produced by the system operation (residence time, water discharge, level fluctuations, advection currents), lead to complex hydrodynamic patterns interfering in the spatial distribution and temporal sequence of the plankton organisms (Tundisi, 1990). The man-induced variations in reservoirs can directly affect zooplankton and some population responses are not clearly discriminated from seasonal influence (Geraldes and Boavida, 2005). Besides the physical parameters, biotic interactions such as fish predation affecting zooplankton fluctuation has also been intensively discussed (Urabe, 1990; Soares and Hayashi, 2005).

Recently new approaches have been used in studies of the zooplankton of reservoirs in the State of São Paulo (southern Brazil), such as the responses to episodic vertical mixing promoted by the impact of subtropical cold fronts (Tundisi et al., 2004) and the influence of long term degradation processes (biomass versus trophic conditions) (Sendacz et al., 2006).

For certain reservoirs, such as the ones used for water supply, the understanding of zooplankton seasonality can be an important factor to be considered for quality management purposes (García et al., 2002).

In Jurumirim reservoir, considered in the present study, several limnological investigations have been 
undertaken over recent years. In terms of temporal dynamics, the monthly variation of the thermal regime and stability, oxygen deficit (Henry 1992, 1993a) and primary production by phytoplankton (Henry, 1993b; Henry et al., 2006); the influence of hydrological seasonality on seston sedimentation and transport (Henry and Maricato, 1996); the space-temporal variation of phytoplankton (Henry et al., 1998), zooplankton (Nogueira, 2001), and physical-chemical variables (Nogueira et al., 1999), have all been analyzed. Shorter periods of time have also been considered for zooplankton studies in Jurumirim: short term (weekly) variability in rainy and dry periods (Panarelli et al., 2001) and vertical migration in nictemeral cycles (Nogueira and Panarelli, 1997). Some interdecade information (70's and 80's) on the composition and abundance of zooplankton has also been provided (Sampaio et al., 2002).

There is no comprehensive theory explaining the seasonal changes or successional trends for the zooplankton community in tropical and subtropical environments. Thus the present work, carried out in Jurumirim reservoir, intended to verify the occurrence of recurrent temporal patterns (along three consecutive years) for the zooplankton assemblages. It aimed to contribute for a better understanding of the factors influencing the competitive ability of the different species.

\section{Study Area}

Jurumirim is the first of a series of eleven reservoirs built in the Paranapanema River, since the 50's, for electric generation. The dam is located at $23^{\circ} 12^{\prime} 17^{\prime \prime} \mathrm{S}$ and $49^{\circ} 13$ ' 19” W, in São Paulo State (Brazil) (Figure 1).
It has an area of $484 \mathrm{~km}^{2}$, and its maximum and mean depths are of 40 and $12.9 \mathrm{~m}$, respectively.

During the study period the less warm months (minimum average air temperature of $10{ }^{\circ} \mathrm{C}$ ) were August 1993 and July 1994. The maximum monthly average temperature $\left(30{ }^{\circ} \mathrm{C}\right)$ occurred in November 1993 , February and December 1994, and January 1995. The mean annual precipitation for the three-year study was 1,658 mm (Jurumirim reservoir Meteorological Station) with the concentration of the rains in summer periods. The winter is characterized as the dry period.

Additional limnological and climatological information of the reservoir during the study period is provided by Henry et al. (2006).

\section{Material and Methods}

The fieldwork was carried out monthly (morning periods) in the lacustrine-dam zone (approximate local depth of $30 \mathrm{~m}$ ) of the Jurumirim reservoir along three consecutive years - from July, 1992 to July, 1995. There is no vegetation influence in this area, being representative of a real pelagic condition. For qualitative analyses zooplankton samples were collected using vertical net hauls, and the quantitative ones through water filtration $(300 \mathrm{~L})$ by a motor pump at $0,5,10,15,20$ and $25 \mathrm{~m}$, since as it is a deep reservoir stratified in spring and summer, it was expected to observe differences between the water layers. For all samples a conical net of $50 \mu \mathrm{m}$ of mesh size was used. Samples were fixed and preserved in $4 \%$ formaldehyde, and are deposited in the freshwater invertebrate collection at the Department of Zoology of the State University of São Paulo (campus of Botucatu).

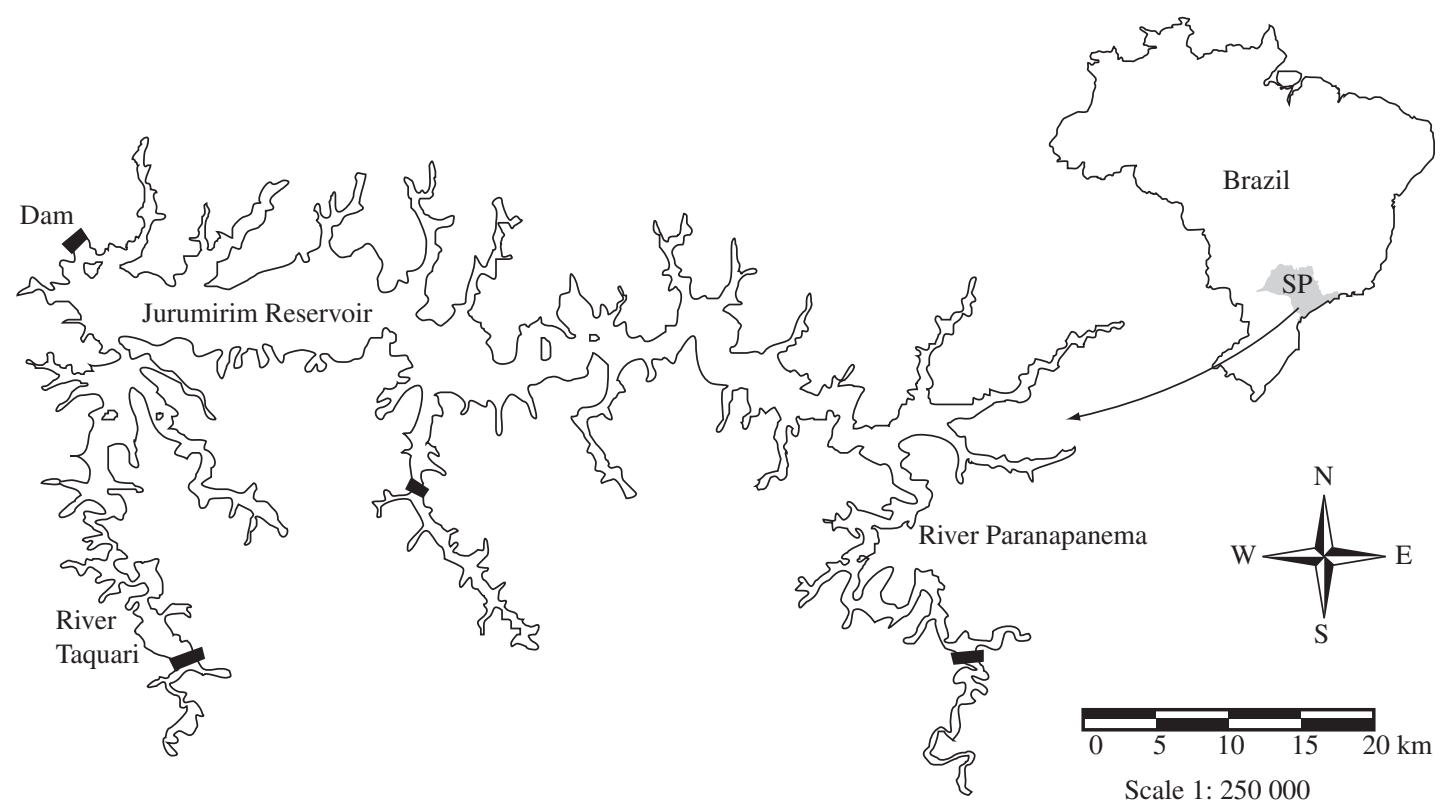

Figure 1. Map of Jurumirim Reservoir. 
For the quantitative analysis the zooplankton was counted using sub samples. A minimum of 200 individuals was considered in each sample or the total sample was analyzed.

For representation purposes, it was considered the abundance in the euphotic zone for the most representative zooplankton species (abundance and occurrence). The graphs illustrating total zooplankton, cladocerans, rotifers and copepods considered the six different studied depths, showing the maximum and minimum densities, standard deviation and mean values.

In order to identify the influence of the environment on the zooplankton dynamics, the following limnological variables were analyzed: Secchi disk transparency, water temperature (surface and bottom) (Toho Dentam thermistor), chlorophyll- $a(0,5,10,15,20$ and $25 \mathrm{~m})$ (cold acetone extraction) and dissolved oxygen analysis $(0,5$, 10, 15, 20 and $25 \mathrm{~m}$ ) (Winkler method) (Golterman et al., 1978). The theoretical water retention time (Straškraba et al., 1993) was estimated using data of water discharge at the dam (monthly mean) and the reservoir volume provided by the electric company. Data on phytoplankton primary production, rain precipitation and other limnological variables were simultaneously obtained and analyzed (Henry et al., 2006).

Analyses searching for statistical relation among the studied variables (e.g. Pearson correlation, PCA and CCA) were performed, but did not produce significant results in terms of correlation. Anyhow some correlations are mentioned in the discussion.

\section{Results}

\subsection{Limnological variables}

Figure 2 shows monthly fluctuations of the theoretical water retention time. The minimum value (181 days) was recorded for February/93 and the maximum for December/93 (576 days). The average theoretical water retention time (RT) for Jurumirim reservoir during the study period was 258 days. Despite the strong seasonal precipitation regime in this region, no clear pattern of variation was observed for the water retention time. However, relatively low values were estimated every summer (February/March, 1993; February/March, 1994; January/February, 1995). Higher variability occurred over the first period of study (1992 and 1993) but for 1994, the RT remained very high (above 464 days), except for the mid-summer months. After February 1995, the values were around 350 days.

Chlorophyll values (water column mean) were generally low (between 1 and $4 \mu \mathrm{g} . \mathrm{L}^{-1}$ ) during the whole study period (Figure 2). An increasing tendency was observed in autumn/winter, and also in certain summer months (December, 1993 and January, 1994).

Water transparency ranged from $1.37 \mathrm{~m}$ (April,1993) to $5.16 \mathrm{~m}$ (January, 1995) (Figure 3). In general, an increasing transparency was observed in summer periods. Nevertheless, a high transparency was also found in June and July, 1994.

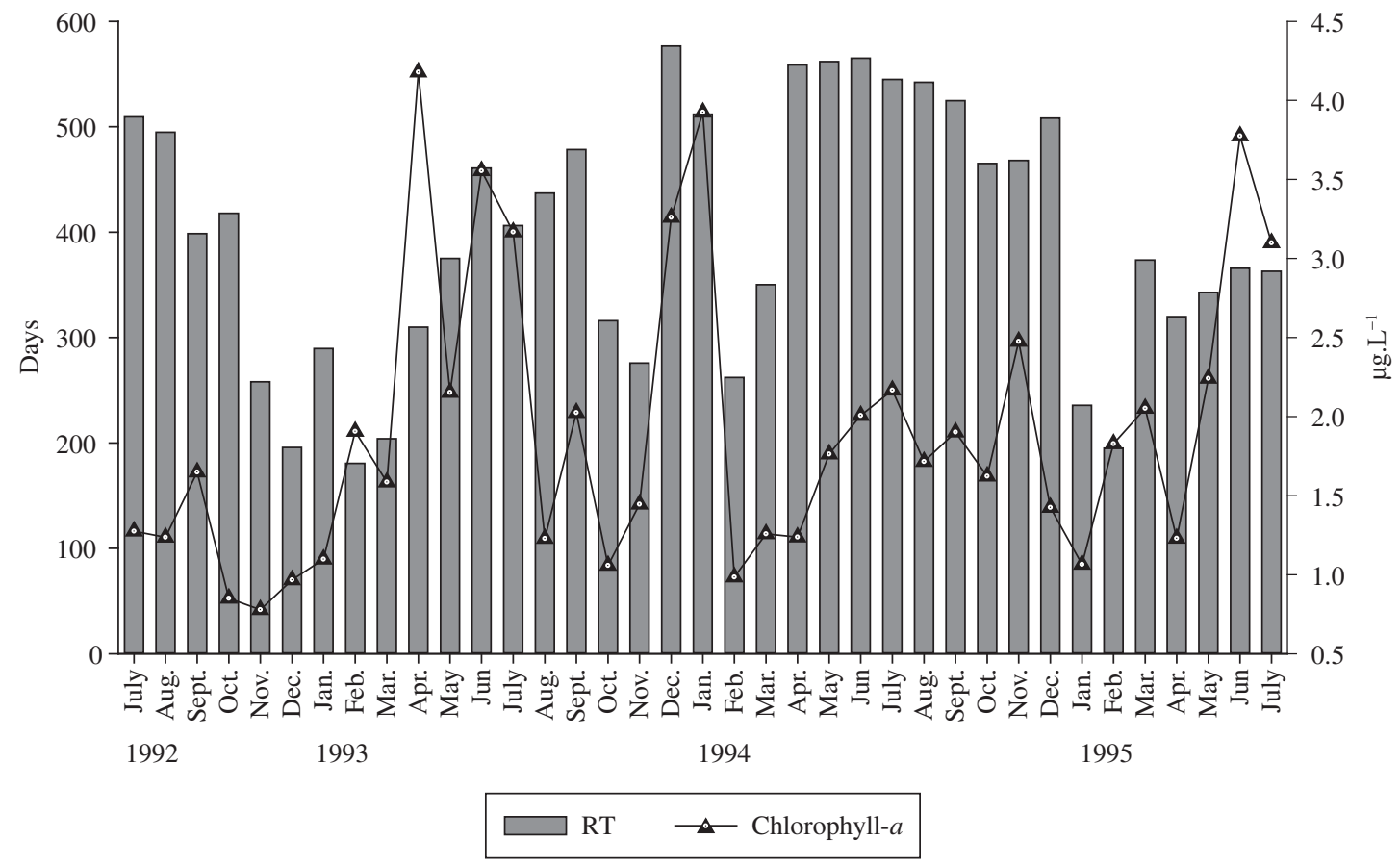

Figure 2. Monthly variation of the theoretical water retention time (RT) and chlorophyll-a concentration in Jurumirim Reservoir between July/92 and July/95. 
Fluctuations of surface and bottom temperature at the sampling station showed a tendency to isothermic conditions during the autumn/winter and great differences in the water column during spring/summer periods (Figure 4). The lowest temperature was observed in August, 1994 (16.9 ${ }^{\circ} \mathrm{C}$ - bottom), and the maximum in January, $1993\left(26.7{ }^{\circ} \mathrm{C}\right.$ - surface). The average of water temperature at the surface and the bottom was, respectively, 22.3 and $19.9^{\circ} \mathrm{C}$.

A clear seasonal pattern of variation was observed for the dissolved oxygen concentrations (Figure 5). Lower mean values for the water column occurred in summer, with the minimum of 6 mg.L ${ }^{-1}$ in March, 1993, and higher values in winter, with the maximum mean value of $9 \mathrm{mg} . \mathrm{L}^{-1}$ in August, 1992 and August, 1994. The oxygen range among depths followed the same temporal pattern with higher amplitude in summer (the highest in March, 1993) and lower in the winter (the lowest in August, 1992).

\section{Zooplankton Assemblages}

In this study 79 different taxa were identified in the zooplankton samples from Jurumirim reservoir (Table 1). Higher richness was observed among the rotifers, with 32 taxa distributed in 25 genera. Cladocera was represented by 17 taxa (11 genera), Copepoda with 3 species of Calanoida (2 genera) and 7 of Cyclopoida (4 genera), one genus of Poecilostomatoida and one unidentified Harpacticoida. Protozoa, represented by 11 different taxa (9 genera), and 7 other zoological groups with episodic occurrence, have not been considered in the quantitative analysis (Table 1). The taxon $C$. cornuta $\mathrm{cf}$. intermedia
Sars, 1886 have also been considered in this study, but its taxonomical status has not yet been confirmed (ElmoorLoureiro, 1997).

Figure 6 shows that the vertical distribution of the zooplankton organisms was more heterogeneous in the first period of study until February, 1994. From this month on, the distribution became much more homogeneous. This figure also shows the monthly fluctuation of abundance (mean water column values), which varied from 2,180 ind. $\mathrm{m}^{-3}$ (November, 1993) to 132,423 ind. $\mathrm{m}^{-3}$ (April, 1993).

Considering the relative abundance among the groups (Figure 7), Rotifera dominated during most of the study period, reaching more than $90 \%$ of the organisms (e.g. in September, 1992). The only period when Copepoda (considering all the development stages) prevailed was in autumn (58\% of total zooplankton in May, 1994 and $48 \%$ in May, 1995). Cladocera was never numerically dominant and their higher proportion was observed in the spring, 1994 and early summer, 1995, reaching the maximum of $25 \%$ of the total organisms (January, 1995).

Figures 8 and 9 show the fluctuation of the abundance of Rotifera and Cladocera, respectively. Due to their dominance, the rotifers had the same variation pattern seen for total zooplankton, with relatively higher values and also more heterogeneous vertical distribution in the first study period. Their mean abundance varied from 972 ind. $\mathrm{m}^{-3}$ (November, 1993) to 79,660 ind. $\mathrm{m}^{-3}$ (August, 1992). The abundance of rotifers varied very irregularly during almost the whole study period.

The cladocerans did not show a clear pattern of temporal fluctuation, but a small decrease of the popu-

1992 1993

1994 1995

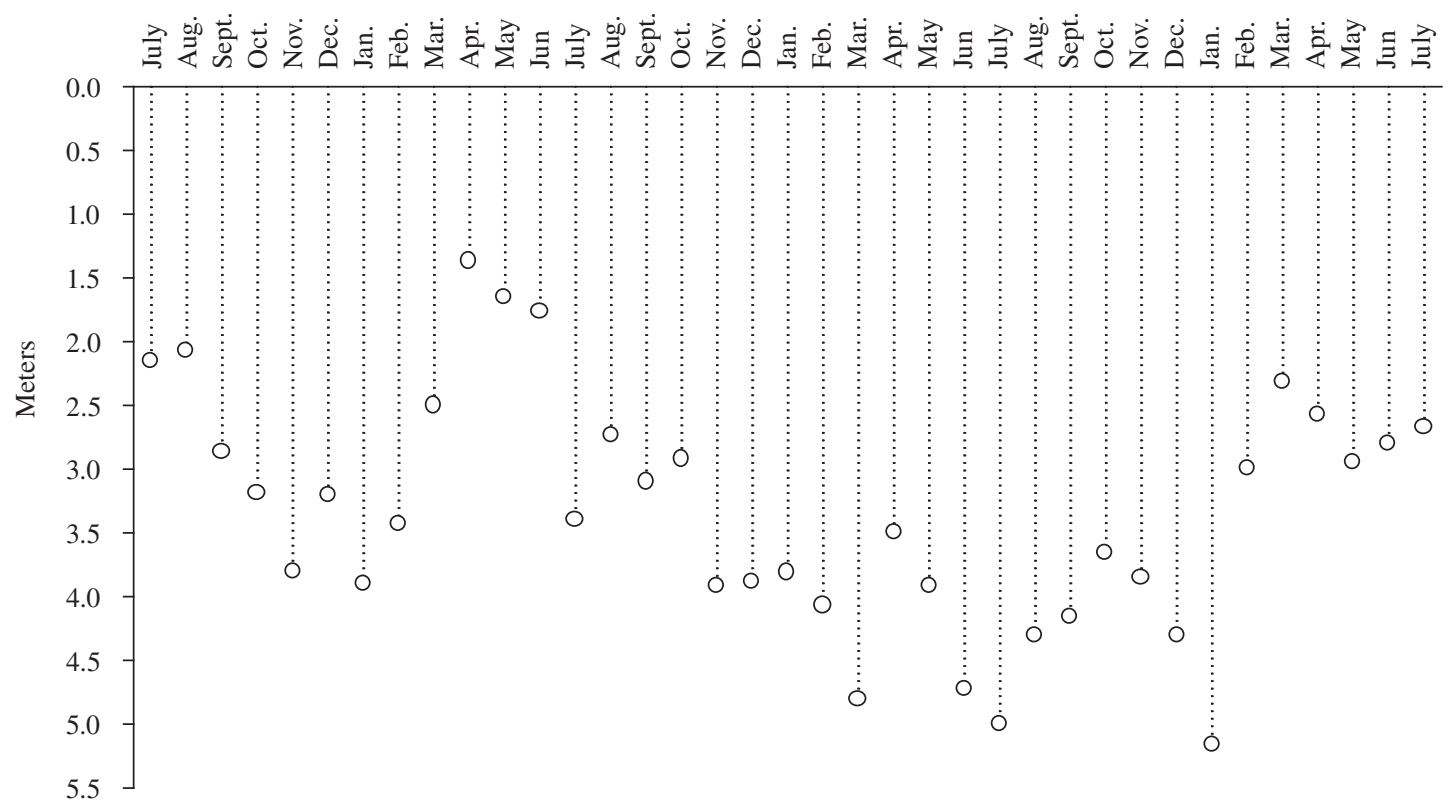

Figure 3. Monthly variation of transparency (by Secchi disk) in Jurumirim Reservoir between July/92 and July/95. 

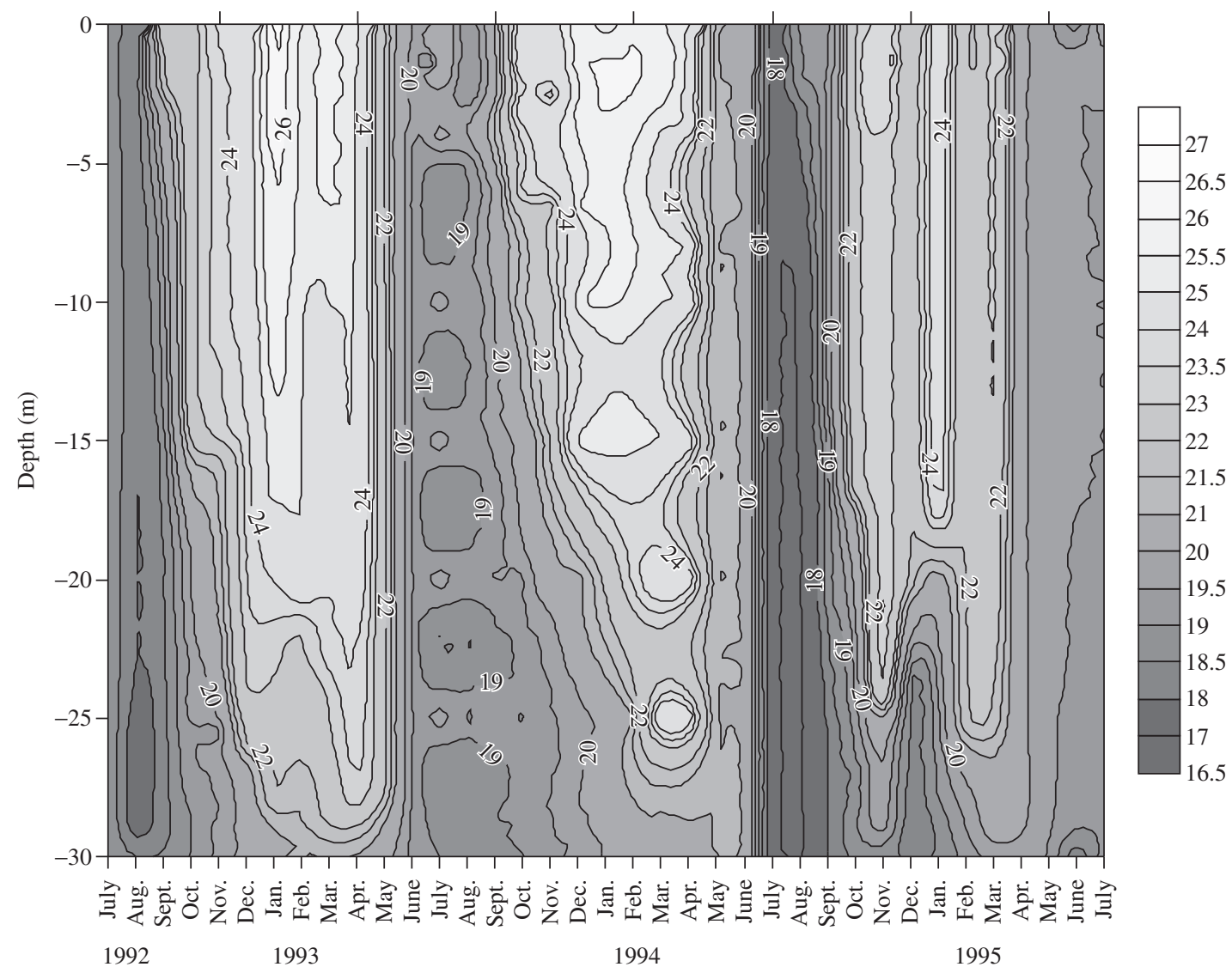

Figure 4. Monthly variation of the temperature in the water column in Jurumirim Reservoir between July/92 and July/95.

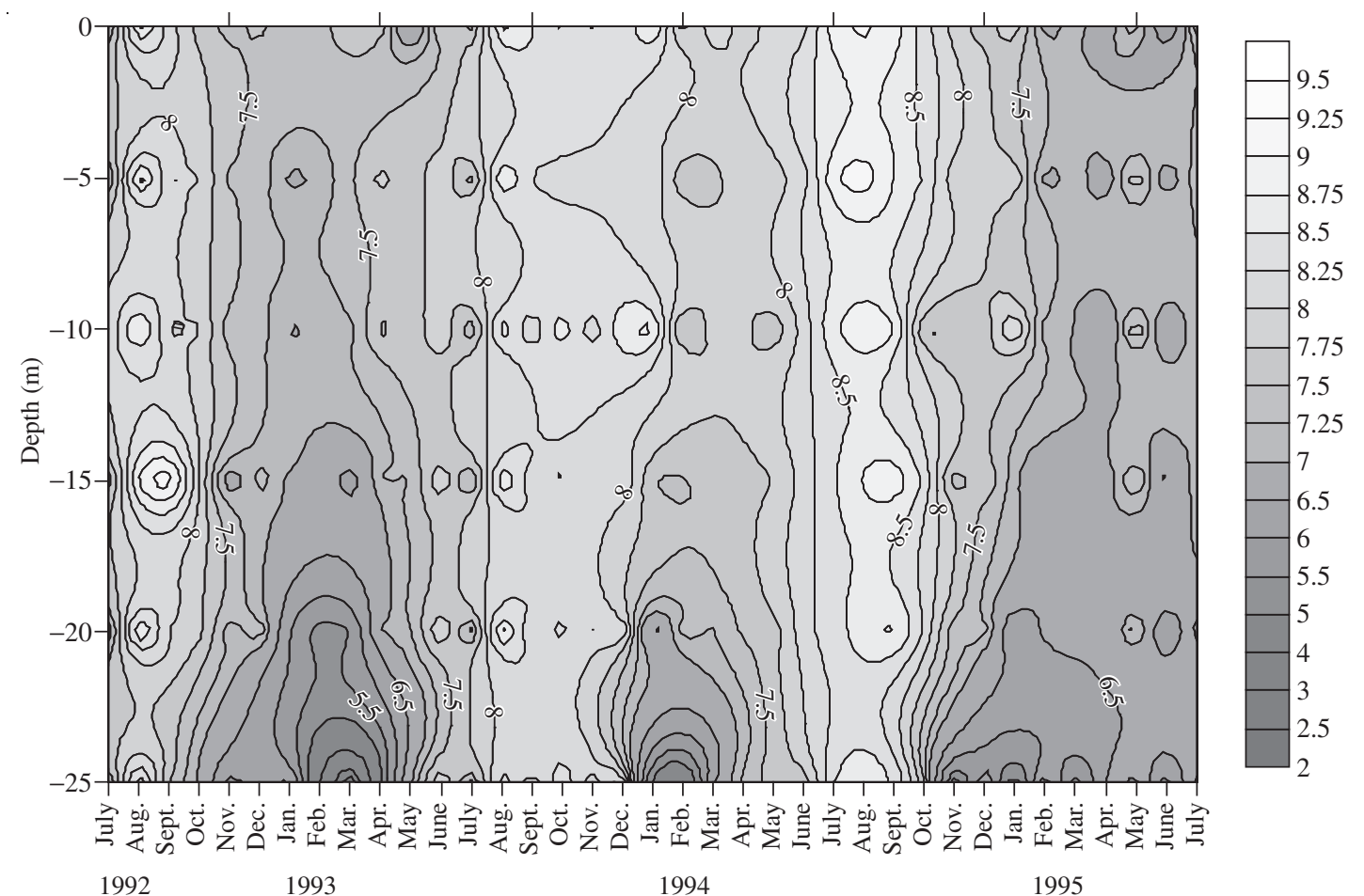

Figure 5. Monthly variation (mean, maximum, minimum and standard deviation) of dissolved oxygen concentrations in Jurumirim Reservoir between July/92 and July/95. 
Table 1. List of the zooplankton taxa sampled in the Jurumirim Reservoir between July/92 and July/95.

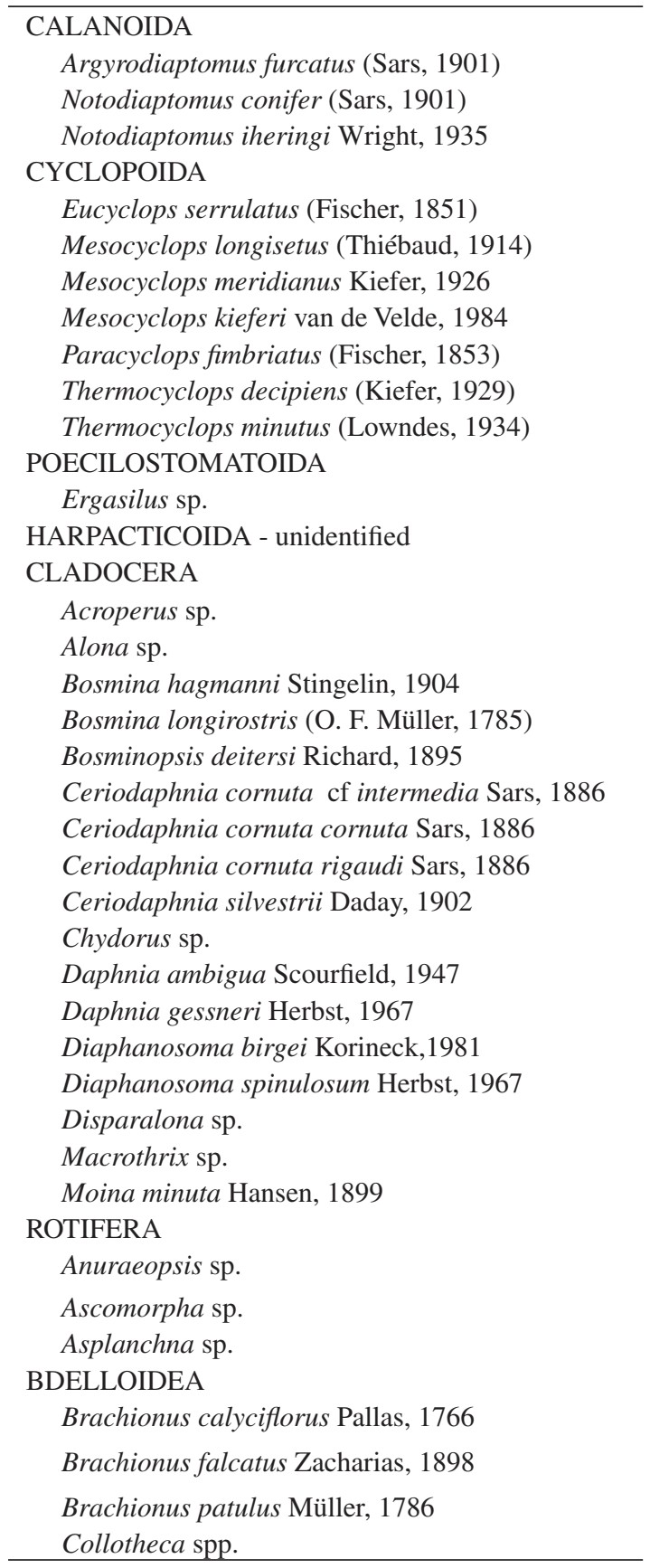

lations seems to occur in winter/spring (Figure 8). The lowest abundance was registered in November, 1993 $\left(61\right.$ ind. $\left.\mathrm{m}^{-3}\right)$. The maximum peaks (water column mean) were observed in autumn, 1993 (April) and spring, 1994 (October) with 7,317 and 6,238 ind. $\mathrm{m}^{-3}$, respectively.

Figure 10 shows the temporal fluctuation of Calanoida and Cyclopoida copepods. Higher abundance of organisms was observed in winter, and lower in summer or late spring/summer. A homogeneous vertical dis-
Table 1. Continued..

Conochiloides sp.

Conochilus sp.

Conochilus unicornis Rousselet, 1892

Epiphanes senta Müller, 1773

Euchlanis sp.

Filinia sp.

Gastropus sp.

Hexarthra spp.

Keratella americana Carlin, 1943

Keratella cochlearis (Gosse, 1851)

Keratella lenzi Hauer, 1953

Keratella tropica Apstein, 1907

Lecane sp.

Lepadella sp.

Paracolurella sp.

Philodina sp.

Platyias quadricornis Ehrenberg, 1832

Polyarthra sp.

Polyarthra vulgaris Carlin, 1943

Pompholyx sulcata Hudson, 1885

Squatinella sp.

Synchaeta sp.

Testudinella sp.

Tricocherca spp.

PROTOZOA

Arcella costata Ehrenberg, 1847

Arcella hemisphaerica Perty, 1852

Arcella sp.

Centropyxis sp.

Codonella sp.

Difflugia sp.

Pleurotricha sp.

Raphidiophyrys sp.

Thecamoeba sp.

Tintinopsis sp.

Vorticella sp.

Other Zoological Groups

Chaoboridae

Chironomidae

Gastrotricha

Hydracarina

Nematoda

tribution was observed either in winter or summer and a higher variation occurred in the autumn/winter, being the highest in April, 1993, despite no thermal stratification occurring in these periods. For the calanoids there was no clear temporal pattern of abundance fluctuation, but the highest vertical variability was also observed in April, 1993, in the early autumn period.

Considering the mean values for the water column, the calanoids were dominant in relation to cyclopoids, 


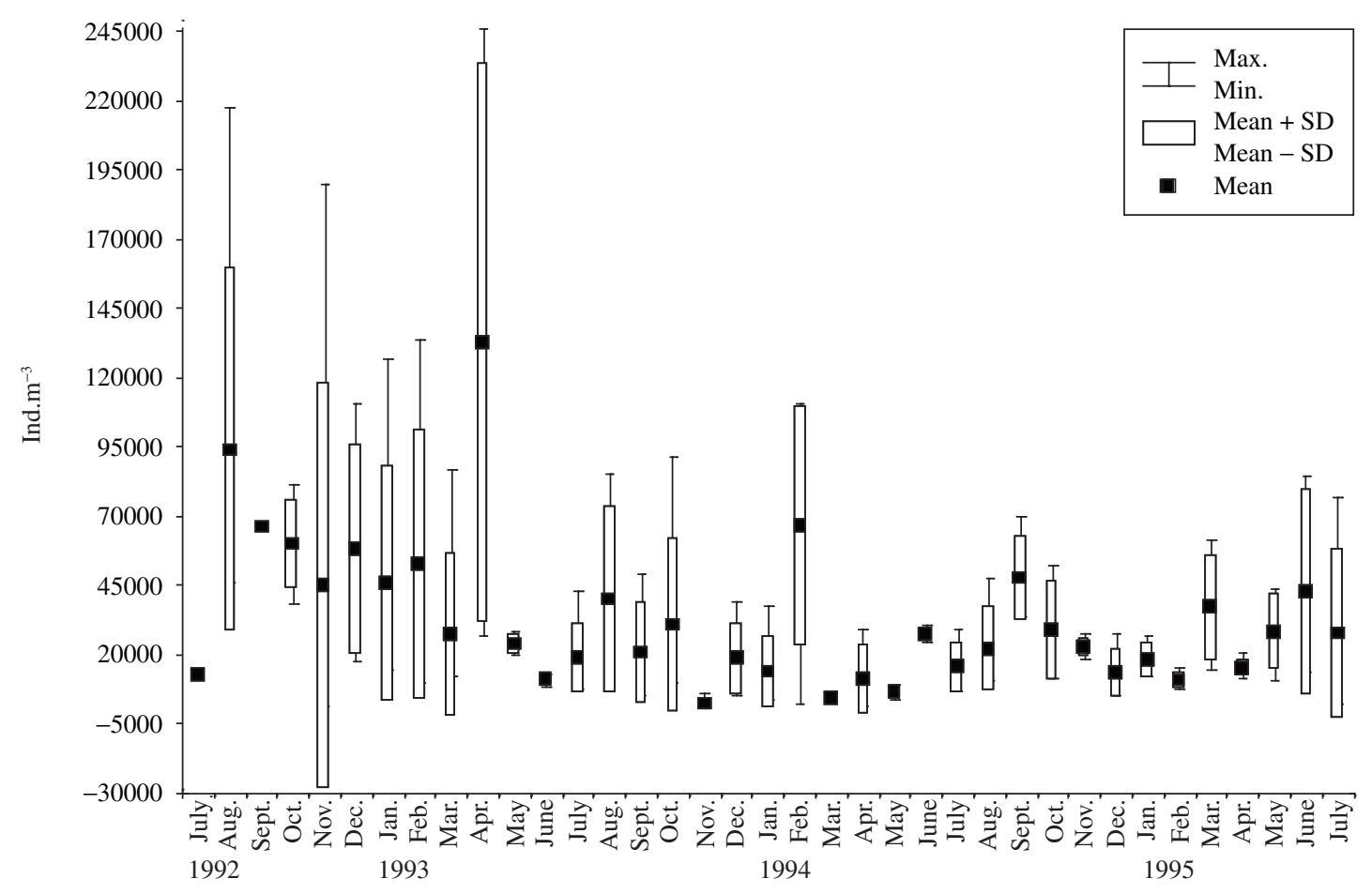

Figure 6. Monthly variation (mean, maximum, minimum and standard deviation) of total zooplankton abundance in Jurumirim Reservoir between July/92 and July/95.

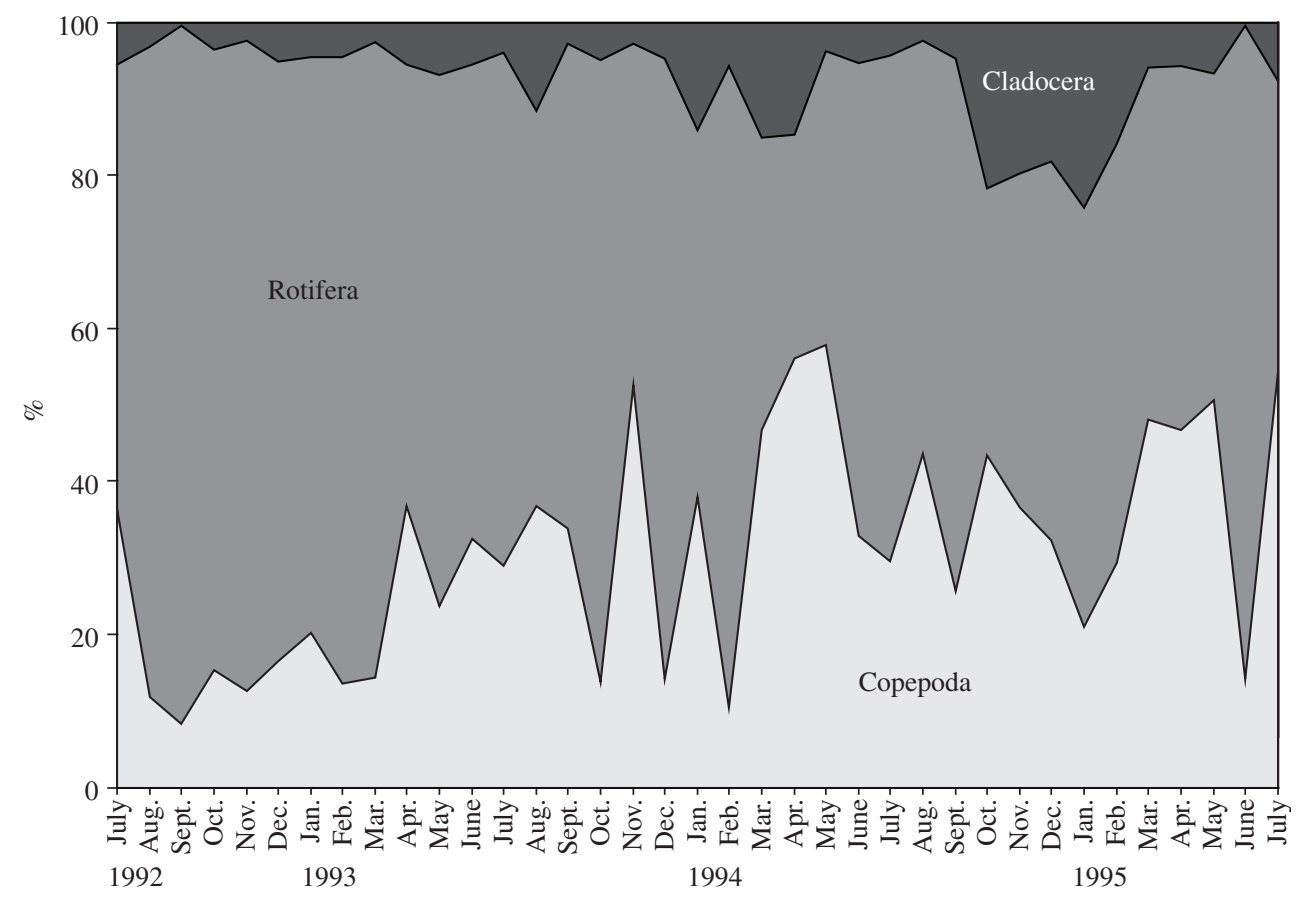

Figure 7. Monthly variation of the relative abundance (mean value for the water column) of Cladocera, Rotifera and Copepoda in Jurumirim Reservoir between July/92 and July/95.

especially in late spring and summer. Conversely, a higher proportion of cyclopoid was observed in the winter (July, 1992, June, 1993 and July, 1995).

The contribution of nauplii in the relative abundance of copepods (Figure 11) is noticeable, but for cyclopoids, the nauplii represented more than $50 \%$ in all months, and several times more than $80 \%$ of the organisms. A small decrease seems to occur in autumn-winter periods. Adults remained in low density most of the time, reaching a maximum of $20 \%$ only once. For Calanoida, there was a lower 


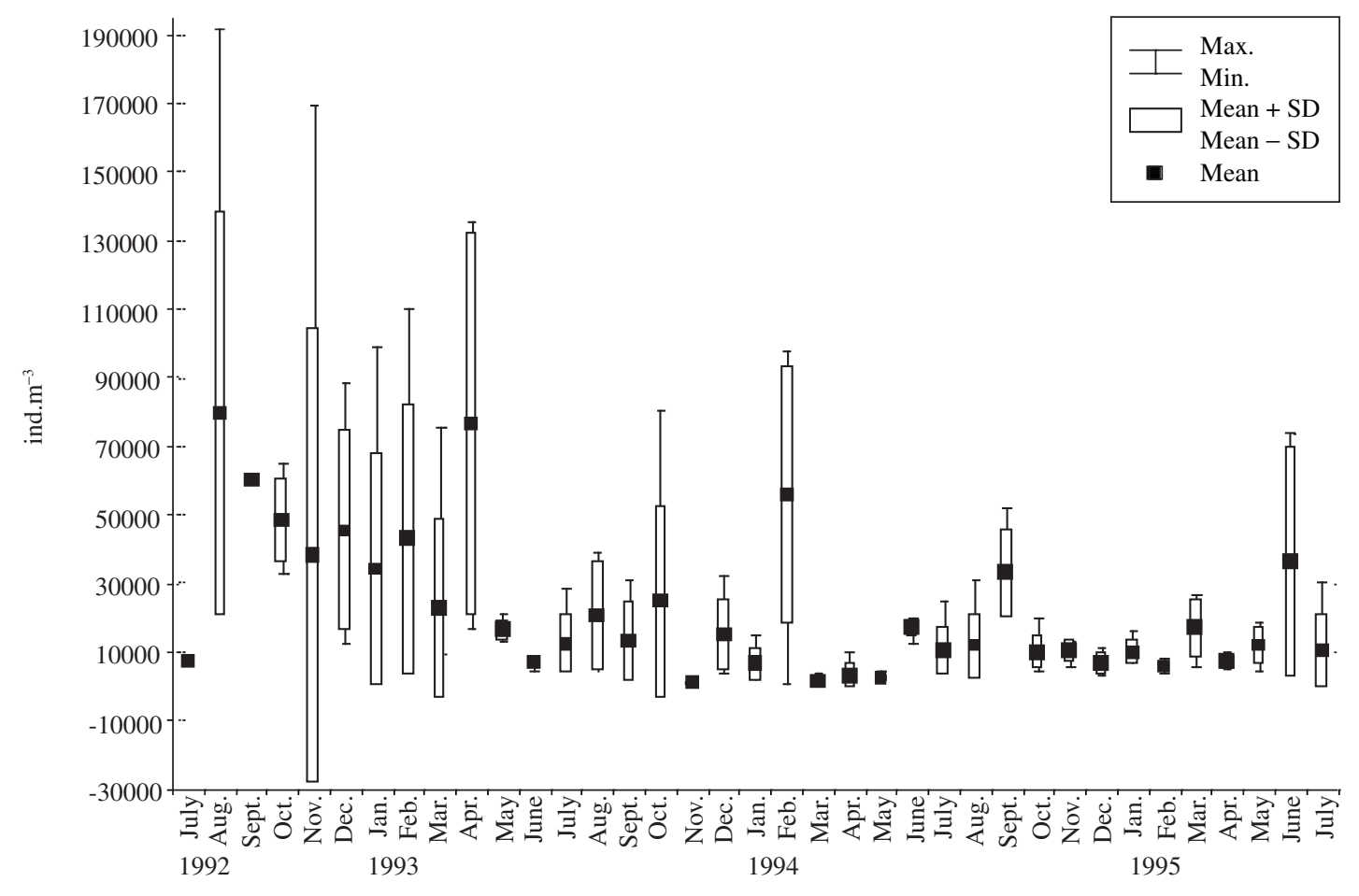

Figure 8. Monthly variation (mean, maximum, minimum and standard deviation) of the abundance of rotifers in Jurumirim Reservoir between July/92 and July/95.

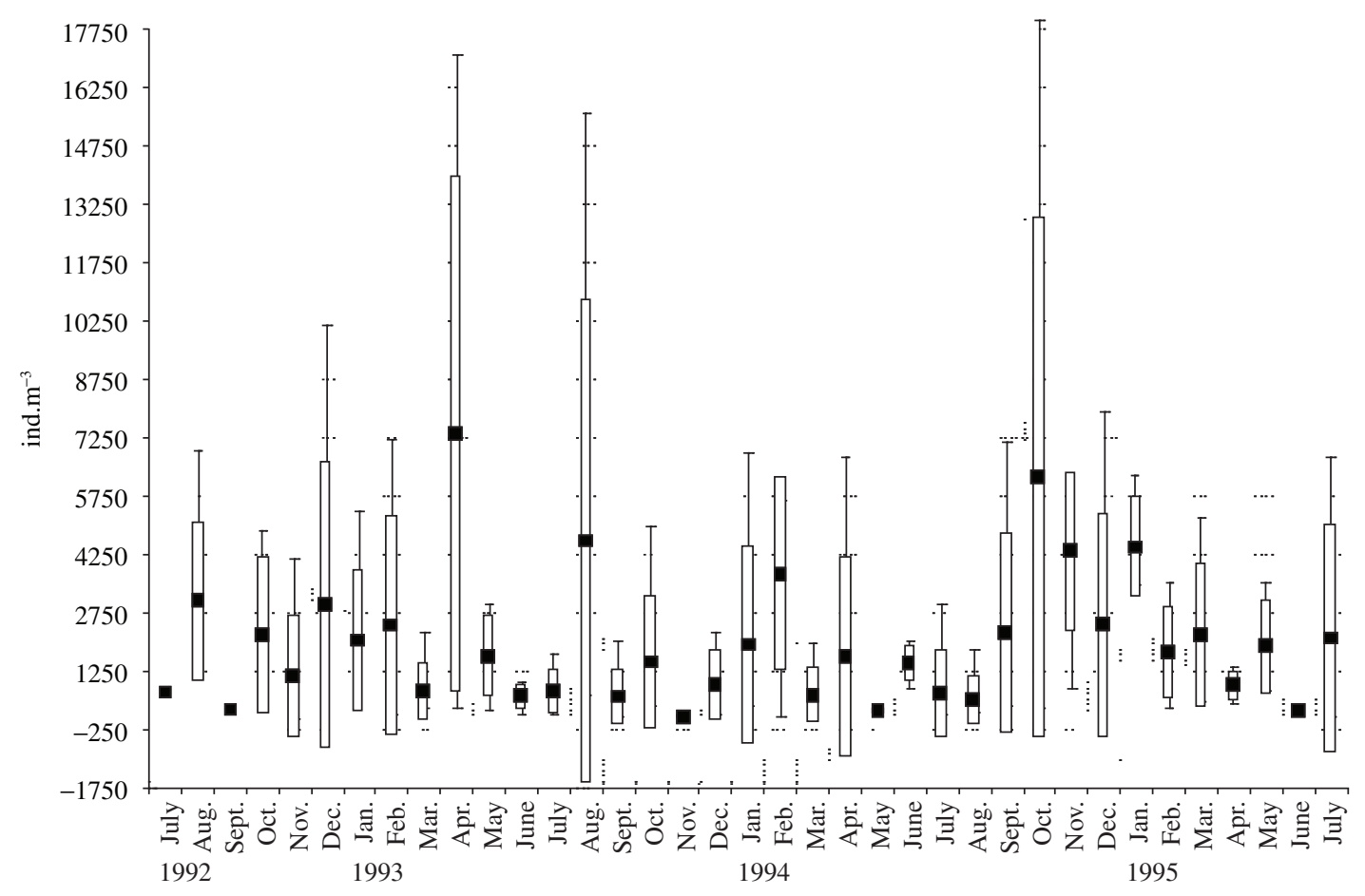

Figure 9. Monthly variation (mean, maximum, minimum and standard deviation) of cladocerans abundance in Jurumirim Reservoir between July/92 and July/95. 

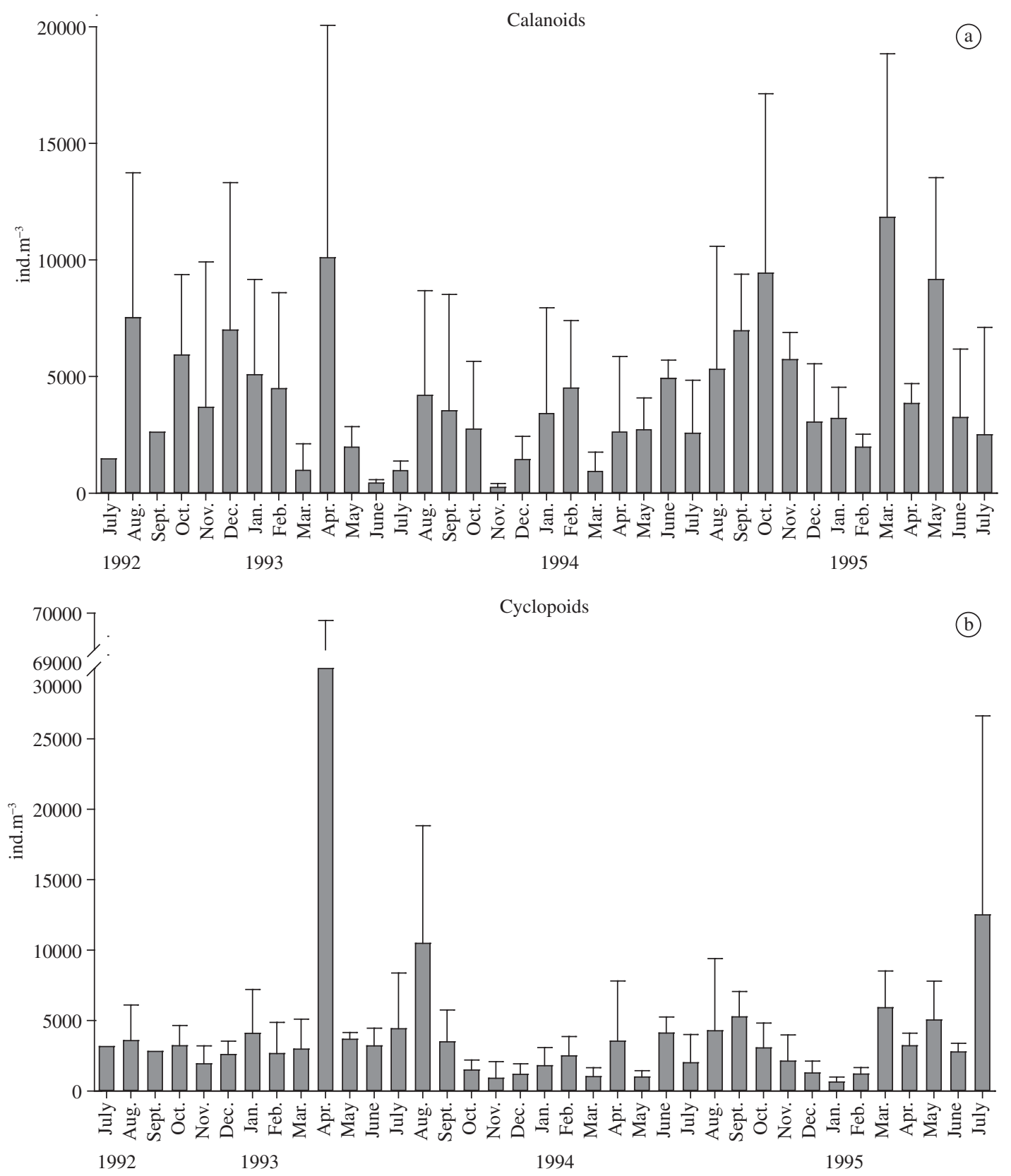

Figure 10. Monthly variation (mean and standard deviation) of a) calanoids and b) cyclopoids, in Jurumirim Reservoir between July/92 and July/95. (Note different scales).

proportion of nauplii and a higher one of copepodids and also a different temporal pattern, with the tendency of higher larvae abundance in summer. The maximum proportion of adults (50\%) occurred in September, 1993.

The temporal fluctuation of the dominant zooplankton taxa is shown in Figures 12 and 13. Certain alternation of the maximum abundance peaks among the main Rotifera species was observed, especially during periods of high abundances (Figure 11a). Conochilus, mainly represented by C. unicornis Rousselet, 1892, reached maxi- mum abundance in spring 1994, with 128,000 ind.m ${ }^{-3}$ (surface). Hexartha spp. showed a maximum density in summer, around 60,000 to 70,000 ind. ${ }^{-3}$ (February, 1993 and 1994) and their distribution seems to be negatively affected by depth. Higher abundance of Keratella (K. americana Carlin, 1943 and K. cochlearis (Gosse, 1851)) occurred in the winter (around 70,000 ind. $\mathrm{m}^{-3}$ August, 1992) and spring (around 50,000 ind. m $^{-3}$ October, 1993). A relatively low seasonal fluctuation of Polyarthra (mainly P. vulgaris) was observed and maxi- 

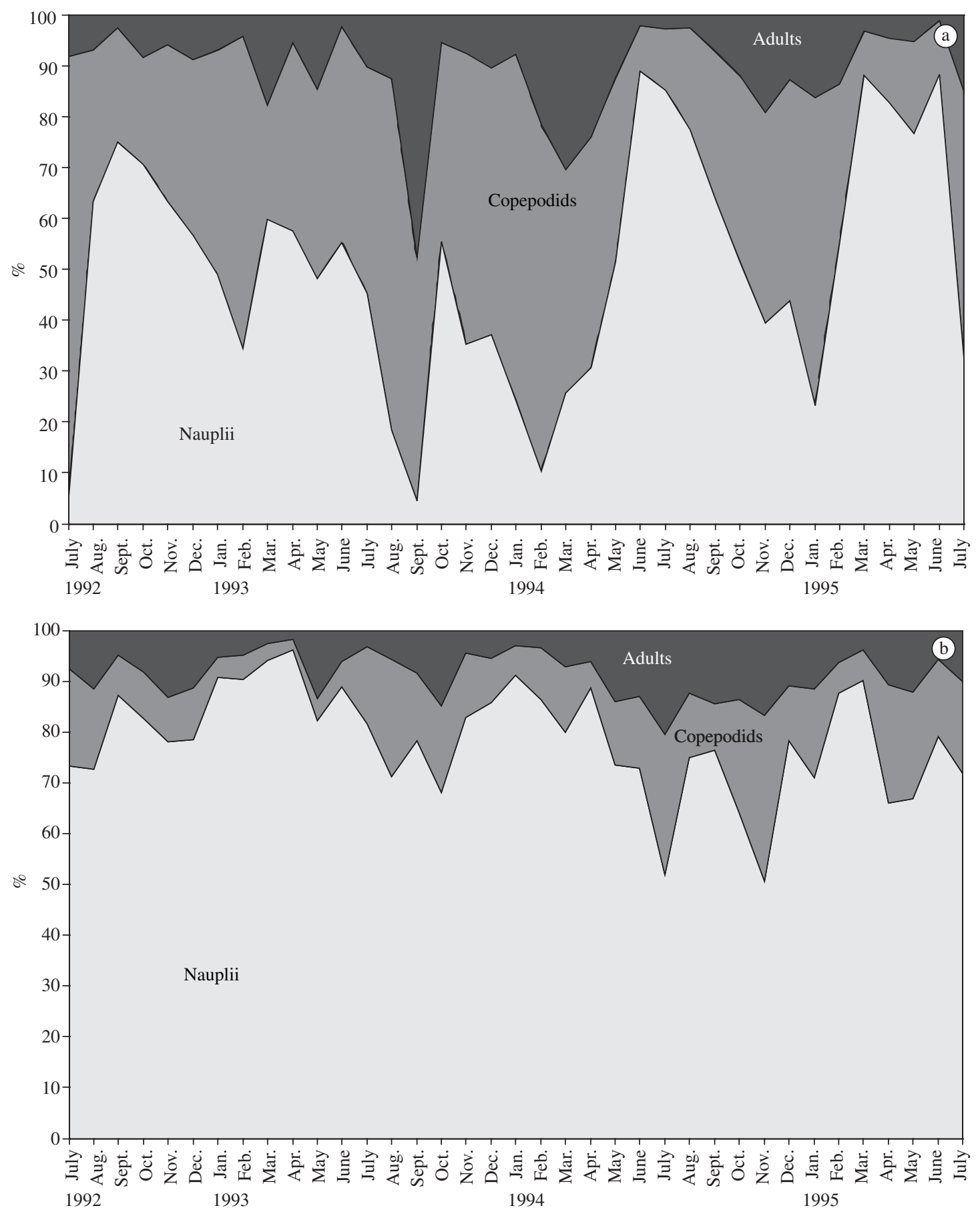

Figure 11. Monthly variation of the relative abundance (mean values of the water column) of adults, copepodids and nauplii of a) calanoids b) and cyclopoids in Jurumirim Reservoir between July/92 and July/95.

mum values of abundance (around 30,000 ind. $\mathrm{m}^{-3}$ ) were registered in winter (August, 1992) as well as in summer (December, 1992). Occasionally, at relatively low rotifer densities (winter, 1994 and 1995), there was a coexistence of the main species, showed by intermediate peaks in abundance.
The abundance fluctuation (surface and bottom) of the three main genera of Cladocera is shown in Figure 12b. Diaphanosoma, mainly represented by D. birgei Korineck, 1981, predominated the whole year with maximum peaks of abundance (above 5,000 ind. $\mathrm{m}^{-3}$ ) in April, 1993 and January, 1995. Some of the peaks of 

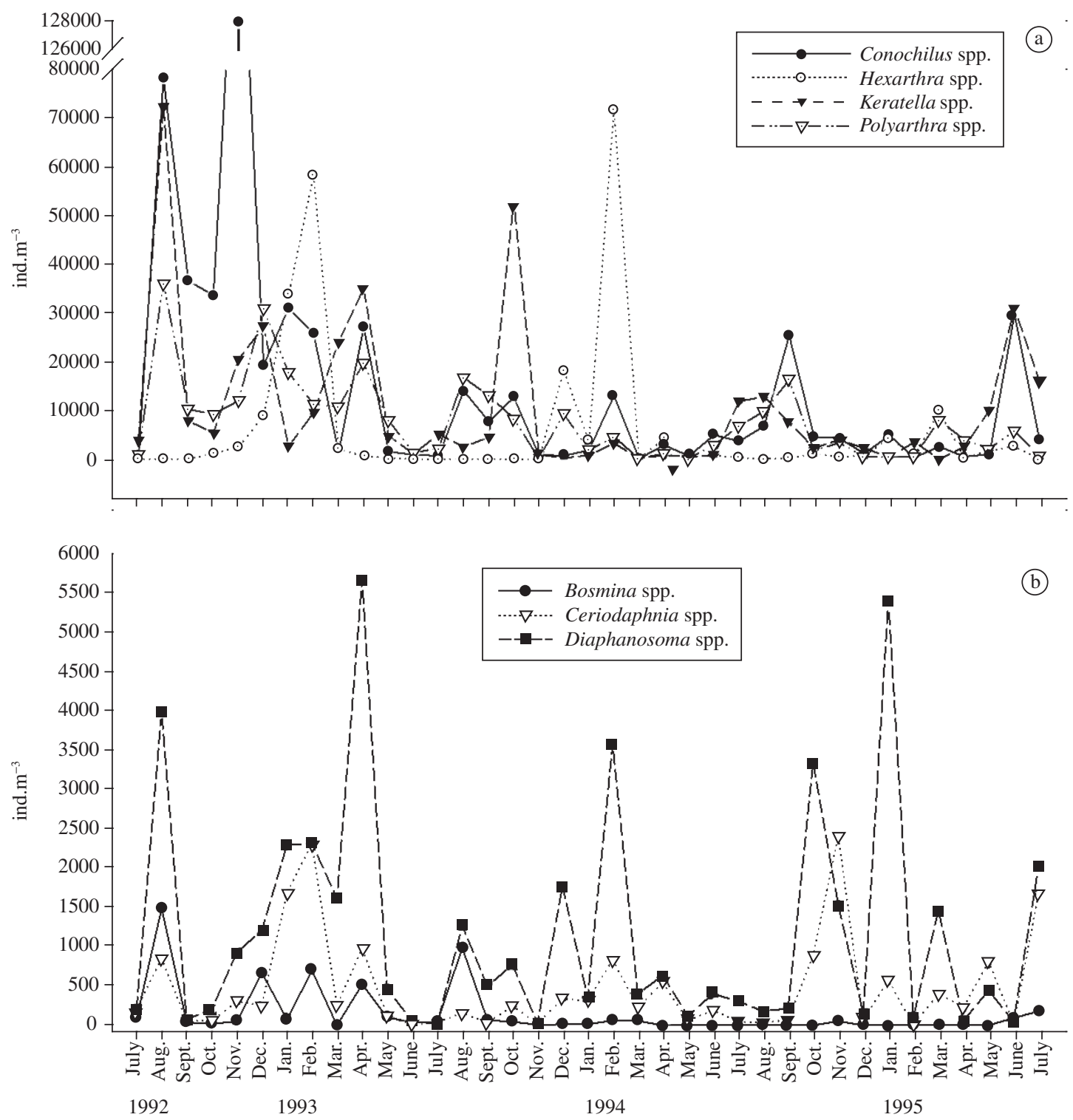

Figure 12. Monthly variation of the abundance of the main a) rotifer and b) cladoceran taxa in Jurumirim Reservoir between July/92 and July/95, on the surface. (Note different scales).

Ceriodaphnia (C. cornuta cornuta Sars, 1886, C. cornuta rigaudi Sars, 1886 and C. silvestrii Daday, 1902), although in smaller abundance, coincided with the ones of Diaphanosoma. Bosminidae were represented mostly by Bosmina hagmanni Stingelin, 1904, occurring throughout the sampling period but always in low abundance $\left(<1,500\right.$ ind. $\left.\mathrm{m}^{-3}\right)$. The other genus of Bosminidade, Bosminopsis deitersi Richard, 1895, rarely occurred.

The Calanoida main species, Notodiaptomus iheringi Wright, 1935 and Argyrodiaptomus furcatus (Sars, 1901), generally had alternating peaks of their maximum abundance (adult stage) (Figure 13). A. furcatus reached extremely high abundance values on the surface, especially in colder periods, and in November, 1994, a peak in the bottom $\left(2,100\right.$ ind. $\left.\mathrm{m}^{-3}\right)$ was also registered.

Cyclopoids were not as abundant as calanoids, and the main taxa were: Thermocyclops decipiens (Kiefer, 1929), T. minutus (Lowndes, 1934) and Mesocyclops spp. (Figure 13). The genus Mesocyclops was represented by M. longisetus (Thiébaud, 1914), M. kieferi (van de Velde, 1984), and M. meridianus Kiefer, 1926. In previous studies of the Jurumirim reservoir, the latter had been erroneously identified as M. brasilianus Kiefer, 1933 (Henry and Nogueira, 1999; Nogueira, 2001). Small abundances 

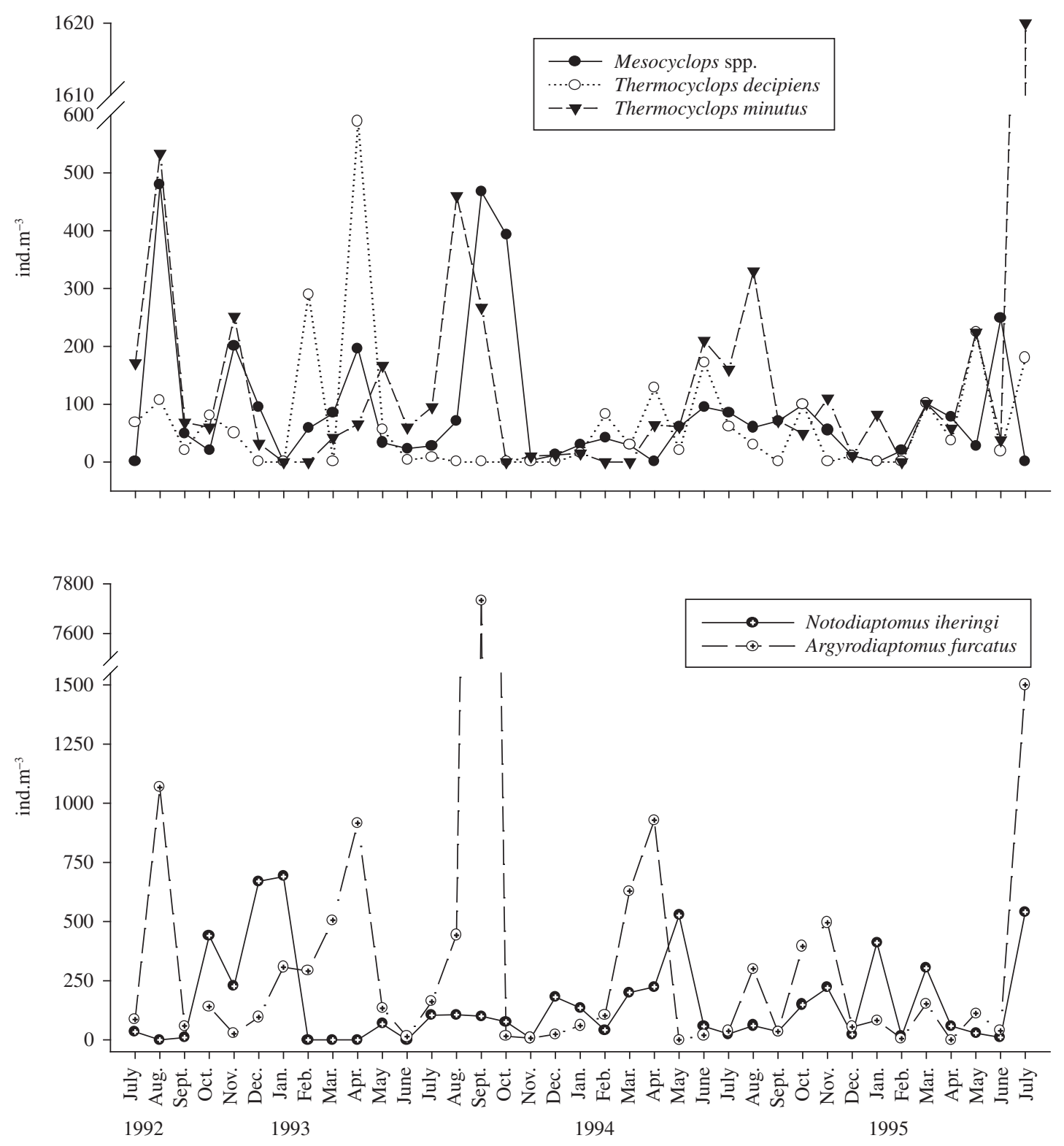

Figure 13. Monthly variation of the abundance of the main taxa of copepods in Jurumirim Reservoir between July/92 and July/95, on the surface. (Note different scales).

of Mesocyclops were observed in summer periods. In June, 1995, T. minutus (Lowndes, 1934) reached its maximum abundance, around 1,620 ind. $\mathrm{m}^{-3}$ (surface). Both Thermocyclops species co-occurred during all the sampling period, but coincident in major abundance peaks were not observed and T. minutus (Lowndes, 1934) reached higher abundance. For $T$. decipiens (Kiefer, 1929), the maximum abundance was registered in late summer, early autumn of 1993 (around 600 ind. m $^{-3}$ ) and for T. minutus (Lowndes, 1934) in winter, 1992 (around 550 ind. $\mathrm{m}^{-3}$ ) and winter, 1995 (around 1,600 ind. $\mathrm{m}^{-3}$ ).
Both species also occupy the whole water column but, comparing surface and bottom data of the first 22 studied months, it is noticeable that T. minutus (Lowndes, 1934) remained in high abundance in deeper layers.

\section{Discussion}

\subsection{General limnological aspects}

Jurumirim is a limnologically well-known reservoir (see Henry and Nogueira, 1999 for a synthesis), large and 
spatially complex with distinct longitudinal and lateral compartments (Henry and Maricatto, 1996; Henry et al. 1998; Nogueira et al., 1999). Another important feature of the reservoir is the association of its upper zone (70 to $80 \mathrm{~km}$ far from the dam) to a group of adjacent ecosystems (marginal lagoons and riverine mouths), which has a great importance in the biogeophysical processes and supports a high biological diversity (e.g. Carvalho and Silva, 1999; Henry, 2003).

The lacustrine zone of the reservoir, near to the dam, can be classified as oligotrophic (Henry et al., 1998; Nogueira et al., 1999) and warm monomictic system (Henry, 1993a) with a hypolimnetic oxygen deficit at the end of the stratified period (late summer) (Henry, 1992).

The temporal fluctuation of the Jurumirim reservoir limnological characteristics is mainly influenced by variation in the rains and water retention time (Henry et al., 2006). The variation of the precipitation along the annual cycle is well defined, with rains concentrated in late spring and summer. During the study period this seasonal pattern was very clear. The water retention time (RT) in Jurumirim is high with the annual mean between 400 to 600 days (Nogueira et al., 2005). However, variation in total water discharge and as a consequence in the RT is not clearly defined, because it depends on the market demand for electricity and level control of the downstream reservoirs.

During the study period the RT varied irregularly, but with a certain decrease in the rainy periods (summer). The minimum RT that was estimated during the study period, 181 days, is still long enough to affirm that Jurumirim, at least the large region near the dam, is a typical lacustrine environment. This condition is quite different from other reservoirs in the basin, such as Salto Grande and Canoas I and II, where the mean RT is less than 2, 7 and 5 days, respectively (Nogueira et al., 2005).

The influence of the seasonal rains on the studied region of the reservoir is not immediate, due to the permanently high RT. Evidence of this fact is given by the water transparency pattern. Higher transparency is observed in summer, the period of more intensive rains as said before. That is because, as shown by Henry and Maricatto (1996), the sedimentation of most of the alloctonous material brought by rains occurs in the upper zones of the reservoir, where a conspicuous decrease in transparency (pulse effect) occurs in the rainy period (Nogueira et al., 1999). The material that remains suspended, mostly fine mineral particles, will only be detected in the dam zone after a certain time, maybe two or three months depending on the outflow management.

Most values of chlorophyll (mean for the water column) at the dam zone of Jurumirim reservoir were around or even lower than $2 \mu \mathrm{g}$. $\mathrm{L}^{-1}$. The oligotrophic condition of this ecosystem and low availability of primary trophic resources is certainly an important factor interfering in the competitive processes among the zooplankton species.
Oxygen variation followed the well-marked pattern of temperature/circulation of the Reservoir (Henry, 1993a). The high oxygenation of the water mass in winter is related to the increase in the mixture rate between the surface and the bottom layers, in addition to the temperature decrease. The concentration of dissolved oxygen only reached low values in the bottom, during summer. Another factor that may also be associated to the oxygen dynamics is the phytoplankton development, as an increasing tendency of the chlorophyll values in autumn and winter was observed. A similar pattern was detected by Henry et al. (2006) when analyzing phytoplankton primary productivity data. The authors discussed the results in relation to nutrient concentration and $\mathrm{Z}_{\mathrm{EU}} / \mathrm{Z}_{\mathrm{MIX}}$ ratios.

Statistical analysis (Pearson correlation) showed a positive correlation between chlorophyll and RT (e.g. 1994 data), and between transparency and RT. In the case of oxygen, there was an inverse tendency with the temperature range (amplitude of variation) in the water column. However, as the correlation analysis correlation scores were very low, the results were not presented. A PCA analysis (20 limnological variables) undertaken by Henry et al. (2006), for the same sampling period, revealed that the main factors influencing the variability among months were nutrient concentrations and the $\mathrm{Z}_{\mathrm{EU}} /$ $\mathrm{Z}_{\mathrm{MIX}}$ ratio.

\subsection{Zooplankton composition and seasonal fluctuation}

Changes in temperature might act as a trigger of seasonal processes, influencing the zooplankton directly (e.g. metabolic rates) or indirectly (e.g. modifications of the phytoplankton structure). In temperate lakes there is a noticeable decrease on zooplankton density in winter and increase and appearance of new species in other periods. However, this pattern is not so clear in tropical lakes (Arcifa et al., 1992), where factors such as precipitation regime and light penetration can be more important for seasonal dynamics (Rái and Hill, 1981). In Lake Paranoá, an artificial reservoir in Brasília (DF), it was observed a lower zooplankton density in the rainy period, and also an alternation on the seasonal occurrence of certain populations of microcrustaceans, with Thermocyclops decipiens (Kiefer, 1929) being more abundant in the rainy season and Bosmina longirostris (O. F. Müller, 1785) (Cladocera) in the dry period (Pinto-Coelho, 1987).

In Jurumirim, rotifers were the most abundant organisms of zooplankton during almost the entire studied period. These small animals react faster than other zoological groups of freshwater zooplankton to changes in water conditions, due to their short development cycle (r-strategists), being considered as the group with more sensibility to the physical and chemical changes that occur in the environment (Gannon and Stemberger, 1978; Infante, 1982). They can also develop numerous populations using low quality food resources, such as organic detritus (Mangas and Garcia, 1991). The opportunistic strategy of rotifers was reported by Nogueira 
and Matsumura-Tundisi (1996), who studied a seasonal cycle in a very different kind of reservoir, a small and shallow one (Monjolinho reservoir, São Carlos - SP). The authors observed that the succession in plankton assemblages was very influenced by physical forces. The combination of strong winds, high precipitation and low water retention time (late spring and beginning of summer) results in an absolute dominance of rotifers and filamentous diatoms in the plankton.

As a general rule the rotifers dominate zooplankton in Brazilian natural or artificial inland waters (Rocha et al., 1995; Nogueira, 2001; Sendacz and Monteiro Junior, 2003). But it is important to consider that in terms of total zooplankton biomass, they can have only a minor contribution (Matsumura-Tundisi et al., 1989).

The main taxa of Rotifera in Jurumirim were Conochilus, mainly C. unicornis Rousselet, 1892 in spring, Hexartha spp. in summer, Keratella americana Carlin, 1943 and $K$. cochlearis, especially in summer and Polyarthra, mainly P. vulgaris Carlin, 1943, in all seasons.

Rotifers were not dominant only during a few months of the study period, when copepods were numerically more abundant. Higher copepod abundance was associated to periods of increase in the water retention time, as seen between fall and spring of 1994. This could be related to the fact that these organisms have longer and more complex biological cycle (k-strategists), requiring higher environmental physical stability.

The species richness of Copepoda found in the present study was similar to that of the mouth of the Paranapanema river into the Jurumirim reservoir, including two marginal lakes, (3 Calanoida and 6 Cyclopoida taxa) (Casanova and Henry, 2004). A compilation of different studies shows that Copepoda (Calanoida and Cyclopoida of the plankton) in Jurumirim, including the downstream stretch, is represented by 12 taxa (Panarelli et al., 2003).

Calanoida was more abundant in Jurumirim, in relation to Cyclopoida, most of the time. Tundisi et al. (1990) studying the eutrophic Barra Bonita Reservoir, detected the dominance of Cyclopoida among Copepoda, suggesting that this group is more resistant to the decrease in the water quality.

In our study the abundance of Calanoida was especially high in late spring and summer. Conversely, a higher proportion of Cyclopoida was observed in autumn and winter.

An analysis of spatial patterns (longitudinal) and zooplankton distribution in Jurumirim revealed that the proportion of Calanoida increases towards the dam (Panarelli et al., 2003), showing that they are better succeeded in more lacustrine conditions. The authors also observed that Calanoida relative abundance, in relation to Cyclopoida, was higher in the rainy period. Abundance peaks of the large Calanoida Argyrodiaptomus furcatus (Sars, 1901) were related to higher temperatures and rains in the Lobo Reservoir (SP) (Rocha et al., 1995), and to oligotrophic regions in the Furnas Reservoir (Corgosinho and Pinto-Coelho, 2006).

A higher abundance of nauplii, in relation to copepodids and adults, was observed for Cyclopoida. In the case of Calanoida there was a high proportion of juveniles. These facts may indicate the occurrence of a high rate of mortality during the cyclopoids larval phases.

According to Rocha et al. (1995) and Silva and Matsumura-Tundisi (2005) the trophic state of a lake or reservoir seems to determine what species of Thermocyclops will be found. In oligotrophic waters T. minutus (Lowndes, 1934 ) is more frequent while in eutrophic waters it is replaced by $T$. decipiens (Kiefer, 1929). In mesotrophic lakes both species would be found together or in a seasonally alternating pattern. Pinto-Coelho (1987), studying Lake (reservoir) Paranoá (Brasília, DF) had already considered that T. decipiens (Kiefer, 1929) had a higher capability to grow in more eutrophic conditions, represented in that case by the introduction of allocthonous material during the rainy period.

The co-occurrence of T. minutus (Lowndes, 1934) and T. decipiens (Kiefer, 1929), with T. minutus reaching higher abundance, could confirm the transitional state between oligotrophic to oligo-mesotrophic condition of Jurumirim as proposed by Nogueira et al. (2002). Coincidence in major abundance peaks of these species was not observed, indicating a temporal segregation between them. As observed by Panarelli et al. (2001), T. minutus (Lowndes, 1934) was more abundant in the dry period.

A spatial segregation, among depths, in the same period, was also considered as a strategy of coexistence for these species by Nogueira and Panarelli (1997), in a study of zooplankton vertical migration in Jurumirim.

It is interesting to note that in the 70's T. decipiens (Kiefer, 1929) was found to be the most frequent Cyclopoid in the reservoirs of Paranapanema (Sampaio et al., 2002).

Cladocera was never numerically dominant and the main taxa, Bosmina, Ceriodaphnia and Diaphanosoma, occurred in almost the whole study period and did not present a seasonal pattern of fluctuation. Diaphanosoma (mainly D. birgei Korineck, 1981) reached the highest abundance.

The composition of Copepoda and Cladocera is similar to the ones found in material previously sampled in Jurumirim (Nogueira, 2001; Sampaio et al., 2002; Matsumura-Tundisi and Tundisi, 2003) indicating that there was little change in the plankton microcrustaceans from the 70's to 90's. However, samples collected more recently in Jurumirim show that the zooplankton has experienced fast and pronounced modifications in structure, especially for copepod assemblages. The calanoids Argyrodiaptomus furcatus (Sars, 1901) and Notodiaptomus conifer (Sars, 1901), two species of major importance in the past (Sampaio et al., 2002; Matsumura-Tundisi and Tundisi, 2003) nowadays are rare (A. furcatus (Sars, 1901)) or seem to have become regionally extinct (N. conifer (Sars, 1901)) (Nogueira et al., in prep.). Data of this study as well the one of Nogueira 
(2001), show that these species were firstly replaced by $N$. iheringi Wright, 1935 and presently N. c.f. henseni Dahl, 1894 is the dominant calanoid (Nogueira et al., in preparation). Güntzel (2000) also observed the substitution of A. furcatus (Sars, 1901) by N. iheringi Wright, 1935 in Nova Avanhangava reservoir (Tietê River, São Paulo) as a consequence of the eutrophication process in the last two decades.

\subsection{Zooplankton vertical distribution}

Despite the permanently high values, the variability of the water retention time in Jurumirim may have a certain influence on the zooplankton assemblages. Higher variability in the vertical distribution of the total zooplankton that occurred during the first 20 months of study can be related with higher variability in the water retention time in the same period. Nogueira and Panarelli (1997) had already observed that the behavior of zooplankton vertical migration toward the surface during the night is more distinctive in winter, when RT is higher.

The seasonal stratification regime of Jurumirim reservoir and its effects on the limnological conditions seems not to be an imperative factor controlling the vertical distribution of the zooplankton organisms, as most species could be found in the bottom layer during all seasons.

For copepods, homogeneous distributions in the water column were observed even in periods of the year with great differences between surface and bottom temperatures (e.g. January-February, 1995 for cyclopoids, and February, 1995 for calanoids). The most heterogeneous distribution occurred in autumn, April, 1993, especially due to the nauplii concentrations on the surface (about 73,000 ind. $\mathrm{m}^{-3}$ for Cyclopoida and 21,000 ind. $\mathrm{m}^{-3}$ for Calanoida). In this case a combination of factors certainly had a strong influence determining this distributional pattern. The transparency was the lowest one considering the three year period (less than $1.5 \mathrm{~m}$ ) and there was a high concentration of phytoplankton on the surface (6.46 $\mu \mathrm{g} . \mathrm{L}^{-1}$ of chlorophyll). Thus, the animal distribution on this occasion was possibly associated to the feeding resources distribution. It is also important to consider that at this time of the year, the end of thermal stratification period, there was still a relatively low oxygen concentration in the bottom layer (less than 5 mg.L ${ }^{-1}$ ), despite the relatively low difference in the surface-bottom temperature (c.a. $2{ }^{\circ} \mathrm{C}$ in $30 \mathrm{~m}$ depth). This could be an additional factor limiting a deeper distribution of the zooplankton organisms.

Rotifers were more abundant at the surface. However, they can occupy the whole water column. Conochilus, for instance, had several peaks of abundance in the bottom (up to 40,000 ind. $\mathrm{m}^{3}$ ), which suggests that the conditions in the hypolimnion do not limit the distribution of this genus, mainly represented by C. unicornis Rousselet, 1892. Among the main taxa of rotifers in Jurumirim, the only one that avoids the bottom layer is Hexarthra.
Cladocera were also found in higher abundance at the surface, but the main taxa were always found in the bottom as well and, in the case of Diaphanosoma, occasionally in relatively high abundance.

\section{Conclusions}

Seasonal effects on the limnological features of the Jurumirim reservoir (e.g. thermal regime, oxygen distribution, phytoplankton biomass) were verified by this study. However, the influence of seasonality on the fluctuation of the zooplankton composition and abundance was not clear. Rotifers were the most abundant organisms with certain seasonal alternation in the abundance peaks of the main taxa (Conochilus unicornis Rousselet, 1892, Keratella americana Carlin, 1943, K. cochlearis (Gosse, 1851) and Hexarthra spp.), except for Polyarthra (mainly P. vulgaris Carlin, 1943). Only occasionally copepods (including all developmental stages) were numerically dominant. Higher copepod abundance was positively associated to periods of increasing water retention time. Among the Copepoda, calanoids (mainly $N$. iheringi Wright, 1935) were more abundant, especially in warmer periods. Conversely, cyclopoids had higher abundance in autumn and winter. The species Thermocyclops minutus (Lowndes, 1934) and T. decipiens (Kiefer, 1929) co-occurred, but the first attained higher abundance, which indicates the oligo-mesotrophic condition of the reservoir. Cladocera was never numerically dominant and the main taxa (Bosmina, Ceriodaphnia and Diaphanosoma) occurred during almost the whole study period and did not present a seasonal pattern of fluctuation. Diaphanosoma (mainly D. birgei Korineck, 1981) attained the highest abundance. Most organisms were always found at the surface, but they also occupy the whole water column, even in periods of stratified conditions low oxygen concentration in the bottom. Among the main zooplanktonic taxa, only Hexarthra avoided deeper layers. An exceptionally high concentration of Copepoda nauplii on the surface was influenced by low transparency, high concentration of phytoplankton in this layer and low oxygen concentration at the bottom. Despite the permanently high values (more than 180 days), the variability of the water retention time (RT) in Jurumirim may have a certain influence on the zooplankton. In periods of higher RT variability, there was a more heterogeneous distribution of zooplankton in the water column. The increase in RT also seems to favour copepod development.

Acknowledgements - This study was supported by FAPESP (Thematic project coordinated by Professor J. G. Tundisi - proc. 91/0612-5 and a scholarship for the last author proc. 92/2696-2) and FUNDUNESP (grant conceded to the second author - proc. $114 / 91 / \mathrm{DFP} / \mathrm{F} / \mathrm{CBS}$ ). The authors wish to express their gratitude to the technician Hamilton Rodrigues for fieldwork support, to Dr. Silvia C. Casanova for providing the map, and to the two anonymous referees that have contributed with very appropriate comments and suggestions.

\section{References}

ARCIFA, MS., GOMES, ET. and MESCHIATTI, AJ., 1992. Composition and fluctuations of the zooplankton of a tropical 
Brazilian reservoir. Archiv für Hydrobiologie, vol.123, no. 4, p. $479-495$.

CARVALHO, ED. and SILVA, VFB., 1999. Aspectos ecológicos da ictiofauna e da produção pesqueira do reservatório de Jurumirim (Alto do Rio Paranapanema, SP). In HENRY, R. (Ed.). Ecologia de reservatórios: estrutura, função e aspectos sociais. Botucatu: Fapesp; Fundibio. p. 771-799.

CASANOVA, SMC. and HENRY, R., 2004. Longitudinal distribution of Copepoda Populations in the transition zone of Paranapanema river and Jurumirim Reservoir (São Paulo, Brazil) interchange with two lateral lakes. Brazilian Journal of Biology, vol. 64, no. 1, p. 11-26.

CONNEL, JH., 1978. Diversity in tropical rain forests and coral reefs. Science, vol. 19, p.1302-1310.

CORGOSINHO, PHC. and PINTO-COELHO, RM., 2006. Zooplankton biomass, abundance and allometric patterns along an eutrophic gradient at Furnas Reservoir (Minas Gerais, Brazil). Acta Limnologica Brasiliensia, vol. 182, p.213-224.

EDMONDSON, WT. and LITT, AH., 1982. Daphnia in Lake Washington. Limnology and Oceanography, vol. 27, p. $272-293$.

ELMOOR-LOUREIRO, LMA., 1997. Manual de identificação de cladóceros límnincos do Brasil. Brasília: Universa. 156 p.

FLÖDER, S. and SOMMER, U., 2000. An experimental test of the intermediate disturbance hypothesis using large limnetic enclosures. Verh International Verein Limnology, vol. 27, p. 2892-2893.

GANNON, JE. and STEMBERGER, RS., 1978. Zooplankton (especially crustaceans and rotifers) as indicators of water quality. Transactions of the American Microscopical Society, vol. 97, no. 1, p. 16-35.

GARCÍA, PR., NANDINI, S., SARMA, SSS., VALDERRAMA, ER., CUESTA, I. and HURTADO, MD., 2002. Seasonal variations of zooplankton abundance in the freshwater reservoir Valle de Bravo (Mexico). Hydrobiologia, vol. 467, p. 99-108.

GERALDES, AM. and BOAVIDA, MJ., 2005. Seasonal water level fluctuations: implications for reservoir limnology and management. Lakes \& Reservoir Management, vol.10, p. 59-69.

GOLTERMAN, HL., CLYMO, RS. and OHNSTAD, MA., 1978. Methods for physical \& chemical analysis of fresh waters. 2 ed. Oxford: Blackwell Scientific Publications. 213p.

GÜNTZEL, A., 2000. Variações espaço-temporais da comunidade zooplanctônica nos reservatórios do médio e baixo rio Tietê/Paraná, SP. São Carlos: Universidade Federal de São Carlos - UFSCar. 445 p. Dissertação de Mestrado.

HENRY, R., 1992. The oxygen deficit in Jurumirim Reservoir (Paranapanema River, São Paulo, Brazil). Japanese Journal of Limnology, vol. 53, no. 4, p. 379-384.

-, 1993a. Thermal regime and stability of Jurumirim Reservoir (Paranapanema River, São Paulo, Brazil). Internationale revue der gesamten Hydrobiologie, vol. 78, no. 4, p. 501-511.

-, 1993b, Primary production by phytoplankton and its controlling factors in Jurumirim Reservoir (Sao Paulo, Brazil). Revista Brasileira Biologia, vol. 53, no. 3, p. 487-499.
HENRY, R. and MARICATTO, FE., 1996. Sedimentation rates of tripton in Jurumirim Reservoir (São Paulo, Brazil). Limnologica, vol. 26, no. 1, p. 15-25.

HENRY, R., NUNES, MA., MITSUKA, PM., LIMA, N. and CASANOVA, SMC., 1998. Variação espacial e temporal da produtividade primária pelo fitoplâncton na represa de Jurumirim (Rio Paranapanema, SP). Revista Brasileira de Biologia = Brazilian Journal of Biology, vol. 58, no. 4, p. 571-590.

HENRY, R. and NOGUEIRA, MN., 1999. A Represa de Jurumirim (São Paulo): primeira síntese sobre o conhecimento limnológico. In HENRY, R. (Ed.). Ecologia de reservatórios: estrutura, função e aspectos sociais. Botucatu: Fundibio; Fapesp.

HENRY, R., 2003. Os Ecótonos nas Interfaces dos sistemas aquáticos: conceitos, tipos, processos e importância. Estudo de aplicação em Lagoas Marginais ao rio Paranapanema na Zona de Sua Desembocadura na Represa de Jurumirim. In HENRY, R. (Ed.). Ecótonos nas interfaces dos ecossistemas aquáticos. São Carlos: RiMa.

HENRY, R., NOGUEIRA, MG., POMPEO, MLL. and MOSCHINI-CARLOS, V., 2006. Annual and short-term variability in primary productivity by phytoplankton and correlated abiotic factors in the Jurumirim Reservoir (São Paulo, Brazil). Brazilian Jounal of Biology, vol. 66, no. 1B, p. 239-261.

HUTCHINSON, GE., 1967. A treatise on limnology: introduction to lake biology and the limnoplankton. New York: John Wiley \& Sons. 1115p.

INFANTE, A., 1982. Annual variations in abundance of zooplankton in Lake Valencia (Venezuela). Archiv für Hydrobiologie, vol. 93, p. 194-208.

KEPPELER, EC. and HARDY, ER., 2004. Vertical distribution of zooplankton in the water column of Lago Amapá, Rio Branco, Acre, Brazil. Revista Brasileira de Zoologia, vol. 21, no. 2, p. 169-177.

MANGAS, E. and GARCIA, H., 1991. Seasonal fluctuations of zooplankton biomass in Lake Xólotlan (Managua). Hydrobiological Bulletin, vol. 24, no. 2, p. 157-162.

MARGALEF, R., 1974. Ecología. Barcelona: Ediciones Omega S.A. $951 \mathrm{p}$.

MATSUMURA-TUNDISI, T., RIETZLER, AC. and TUNDISI, JG., 1989. Biomass of planktonic crustaceans (dry weight and carbon) from Broa Reservoir and its fluctuation across one year (São Carlos, SP - Brasil). Hydrobiologia, vol. 179, p. 229-236.

MATSUMURA-TUNDISI, T. and TUNDISI, JG., 2003. Calanoida (Copepoda) species composition changes in the reservoirs of São Paulo State (Brazil) in the last twenty years. Hydrobiologia, vol. 504, p. 215-222.

NOGUEIRA, MG. and MATSUMURA-TUNDISI, T., 1996. Limnologia de um sistema artificial raso (Represa do Monjolinho - São Carlos, SP): dinâmica das populações fito e zooplanctônicas. Acta Limnologica Brasiliensia, vol. 8, p. $149-168$.

NOGUEIRA, MG. and PANARELLI, E., 1997. Estudo da migração vertical das populações zooplanctônicas na Represa de Jurumirim (Rio Paranapanema - SP). Acta Limnologica Brasiliensia, vol. 9, p. 55-81. 
NOGUEIRA, MG., HENRY, R. and MARICATTO, FE., 1999. Spatial and temporal heterogeneity in the Jurumirim Reservoir, São Paulo, Brazil. Lakes \& Reservoir Management, vol. 4, p. $107-120$.

NOGUEIRA, MG., 2001. Zooplankton composition, dominance and abundance as indicators of environmental compartimentalization in Jurumirim Reservoir (Paranapanema River), São Paulo, Brazil. Hydrobiologia, vol. 455, p. 1-18.

NOGUEIRA, MG., JORCIN, A., VIANNA, NC. and BRITTO, YCT., 2002. Uma avaliação dos processos de eutrofização nos reservatórios em cascata do Rio Paranapanema (SP/PR), Brasil. In CIRELLI, AF. and MARQUISÁ, GC. (Eds.). El agua en Iberoamerica: de la Limnología a la Gestión en Sudamérica. Buenos Aires: Centro de Estudios Transdisciplinarios del Agua - CYTED, Facultad de Ciencias Veterinarias, Universidad de Buenos Aires. Programa Iberoamericano de ciencia y Tecnologia para el Desarrollo.

-, 2005. Reservatórios em cascata e os efeitos na limnologia e organização das comunidades bióticas (fitoplâncton, zooplâncton e zoobentos) - um estudo de caso no rio Paranapanema. In NOGUEIRA, MG., HENRY, R. and JORCIN, A. (Orgs.). Ecologia de reservatórios: impactos potenciais, ações de manejo e sistemas em cascata. São Carlos: RiMa

PANARELLI, EA., NOGUEIRA, MG. and HENRY, R., 2001. Short-term variability of copepod abundance in Jurumirim Reservoir, São Paulo, Brazil. Brazilian Journal of Biology, vol. 61 , no. 4, p. 577-598.

PANARELLI, EA., CASANOVA, SMC., NOGUEIRA, MG., MITSUKA, PM. and HENRY, R., 2003. A comunidade zooplanctônica ao longo de gradientes longitudinais no Rio Paranapanema/ Represa de Jurumirim (São Paulo, Brasil). In HENRY, R. (Ed.). Ecótonos nas interfaces dos ecossistemas aquáticos. São Carlos: RiMa.

PINTO-COELHO, RM., 1987. Flutuações sazonais e de curta duração na comunidade zooplanctônica do Lago Paranoá, Brasilia-DF, Brasil. Revista Brasileira de Biologia $=$ Brazilian Journal of Biology, vol. 47, no. 1-2, p. 17-29.

RÁI, H. and HILL, G., 1981. Bacterial biodynamics in Lago Tupé, a central Amazonian water "Ria Lake". Archiv für Hydrobiologie-Supplement, vol. 58, p. 420-468.

REYNOLDS, CS., 1984. Phytoplankton periodicity: the interactions of form function and environmental variability. Freshwater Biology, vol. 14, p. 111-142.

-, 1993. Scales of disturbance and their role in the plankton ecology. Hydrobiologia, vol. 249, p. 157-171.

ROCHA, O., SENDACZ, S. and MATSUMURA-TUNDISI, T., 1995. Composition, biomass and productivity of zooplankton in natural lakes and reservoirs of Brazil. In TUNDISI, JG.,
BICUDO, CEM. and MATSUMURA-TUNDISI, T. (Eds.). Limnology in Brazil. São Paulo: Brazilian Academy of Sciences and Brazilian Limnological Society.

SAMPAIO, EV., ROCHA, O., MATSUMURA-TUNDISI, T. and TUNDISI, JG., 2002. Composition and abundance of zooplankton in the limnetic zone of the Paranapanema River, Brazil. Brazilian Journal of Biology, vol. 62, no. 3, p. 525-545.

SENDACZ, S. and MONTEIRO Jr., AJ., 2003. Zooplâncton e características limnológicas da planície de inundação do Rio Paraná. In HENRY, R. (Ed.). Ecótonos nas interfaces dos ecossistemas aquáticos. São Carlos: RiMa.

SENDACZ, S., CALEFFI, S. and SANTOS-SOARES, J. 2006. Zooplankton biomass of reservoirs in different trophic conditions in the State of São Paulo, Brazil. Brazilian Journal of Biology, vol. 66, no. 1B, p. 337-350.

SILVA, WM. and MATSUMURA-TUNDISI, T., 2005. Taxonomy, ecology, and geographical distribution of the species of the genus Thermocyclops Kiefer, 1927 (Copepoda, Cyclopoida) in São Paulo State, Brazil, with description of a new species. Brazilian Journal of Biology, vol. 65, no. 3, p. $521-531$

SOARES, CM. and HAYASHI, C., 2005. Interactions of freshwater fish fry with the plankton community. Boletim do Instituto de Pesca, vol. 31, no. 2, p. 175-187.

STRAŠKRABA, M., BLAZKA, P., BRANDL, Z., EJZLAR, P., KOMARKOVA, J., NESMERAK, I., PROCHAZKOVA, I., STRAKRAVOVA, V. and VYHNALEK, V., 1993. Framework for investigation and evaluation of reservoir water quality in Czechoslovakia. In STRAŠKRABA, M., TUNDISI, JG. and DUNCAN, A. (Eds.). Comparative reservoir limnology and water quality management. Dordrecht: Kluwer Academic Publishers.

TALLING, JF. and LEMOALLE, J., 1998. Ecological dynamics of tropical Inland waters. Cambridge: University Pres, 441p.

TUNDISI, JG., 1990. Distribuição espacial, seqüência temporal e ciclo sazonal do fitoplâncton em represas: fatores limitantes e controladores. Revista Brasileira de Biologia $=$ Brazilian Journal of Biology, vol. 50, no. 4, p. 937-955.

TUNDISI, JG. and MATSUMURA-TUNDISI, T., 1990. Limnology and eutrophication of Barra Bonita Reservoir, S. Paulo State, Southern Brazil. Archiv für Hydrobiologie Beiheft Ergebnisse der Limnologie, vol. 33, p. 61-676.

TUNDISI, JG., MATSUMURA-TUNDISI, T., ARANTES Jr., JD., TUNDISI, JEM., MANZINI, NF. and DUCROT, R., 2004. The response of Carlos Botelho (Lobo, Broa) Reservoir to the passage of cold fronts as reflected by physical, chemical, and biological variables. Brazilian Journal of Biology, vol. 64, no. 1, p. $177-186$ 